\title{
LA INTERNACIONALIZACIÓN DE LA CARTA MAGNA ESPAÑOLA DE 1978: SIGNO DE MADUREZ CONSTITUCIONAL
}

\author{
LUIS JIMENA QUESADA
}


SUMARIO

1. CUESTIONES PRELIMINARES: LA INFLUENCIA DE LOS ESTÁNDARES INTERNACIONALES EN LA ELABORACIÓN DE LA CONSTITUCIÓN DE 1978 Y LA NECESARIA COHERENCIA CON LA REALIDAD DEL ESTADO SUPRANACIONAL E INTERNACIONALMENTE INTEGRADO. 2. CUESTIONAMIENTOS SUCESIVOS: EL PESO DEL ENCLAUSTRAMIENTO DE LA JURISDICCIÓN CONSTITUCIONAL ANTE LOS PARÁMETROS INTERNACIONALES. 3. CUESTIONARIOS ULTERIORES: LA PRESENCIA DE UN CONSTITUCIONALISMO ENSIMISMADO CON RESPECTO A LAS FUENTES INTERNACIONALES EN GENERAL Y RELATIVAMENTE ENTUSIASMADO CON RELACIÓN A LAS FUENTES EUROPEAS EN PARTICULAR. 4. LAS CLÁUSULAS CONSTITUCIONALES DE APERTURA INTERNACIONAL: ESPECIAL CONSIDERACIÓN DE LOS INSTRUMENTOS DE DERECHOS HUMANOS. 5. LA POSICIÓN CONSTITUCIONAL DE LOS TRATADOS INTERNACIONALES Y EL LLAMADO CONTROL DE CONVENCIONALIDAD. 6. LA AFECTACIÓN FAVORABLE DE LAS NORMAS INTERNACIONALES AL BLOQUE DE VALORES, PRINCIPIOS Y DERECHOS CONSTITUCIONALES. 7. LA INFLUENCIA DE LOS CÁNONES INTERNACIONALES EN LA ORGANIZACIÓN DE LOS PODERES. 8. EL PAPEL POSITIVO DE LOS INSTRUMENTOS INTERNACIONALES EN LA DEFENSA DEL ORDEN CONSTITUCIONAL. 8.1. La internacionalización de la función constituyente y la ponderación de la reforma constitucional. 8.2. Los cánones internacionales y la jurisdicción constitucional. 8.3. La inadmisible banalización del Derecho internacional y del Derecho constitucional. 9. LA CONSIDERACIÓN DE LAS NORMAS CONSTITUCIONALES POR LOS INSTRUMENTOS INTERNACIONALES: EL MARGEN DE APRECIACIÓN NACIONAL, LA TEORÍA DE LOS CONTRA-LÍMITES Y NOCIONES AFINES. 10. REFLEXIONES FINALES: LA RETROALIMENTACIÓN DE LOS ESTÁNDARES INTERNACIONALES Y CONSTITUCIONALES. 


\title{
LA INTERNACIONALIZACIÓN DE LA CARTA MAGNA ESPAÑOLA DE 1978: SIGNO DE MADUREZ CONSTITUCIONAL ${ }^{1}$
}

\author{
LUIS JIMENA QUESADA
}

\author{
I. CUESTIONES PRELIMINARES: LA INFLUENCIA DE LOS \\ ESTÁNDARES INTERNACIONALES EN LA ELABORACIÓN DE LA \\ CONSTITUCIÓN DE 1978 Y LA NECESARIA COHERENCIA CON \\ LA REALIDAD DEL ESTADO SUPRANACIONAL E \\ INTERNACIONALMENTE INTEGRADO
}

De entrada, un análisis del debate constituyente y del Texto Constitucional que alumbró en 1978 permite comprobar que nuestra Carta Magna no dio una respuesta total, homogénea y ordenada a las exigencias de la actividad exterior del Estado en el orden constitucional, sino que ofreció una cierta asistemática y alusiones dispersas a los estándares nacionales, más variada pero menos contundente que el antecedente de la Constitución republicana de $1931^{3}$. Cabe aclarar, desde este momento, que el presente trabajo se centra en esos estándares del Derecho internacional y, no en los referentes extranjeros de Derecho comparado ${ }^{4}$.

1 El presente trabajo se ha elaborado en el marco de la «Red temática en justicia constitucional y diálogo judicial» (acrónimo: JUDICO) financiada por el MINECO (Acciones de dinamización «Redes de excelencia», referencia DER2016-81801-REDT), cuyo investigador principal es el Dr. Luis Ignacio Gordillo Pérez.

2 Catedrático de Derecho Constitucional de la Universidad de Valencia. Departamento de Derecho Constitucional y Ciencia Política y de la Administración (Facultad de Derecho - Universidad de Valencia). Avda.dels Tarongers, s/n. 46022 Valencia (España). Email: luis.jimena@uv.es

3 Dentro de su Título preliminar, el art. 7 de la Constitución de 1931 disponía que «el Estado español acatará las normas universales del Derecho internacional, incorporándolas a su derecho positivo».

4 Tanto para esos antecedentes del constitucionalismo histórico (por referencia especial a la Constitución de 1931 y a la postura del Tribunal Supremo español con relación a la aplicación de las normas internacionales) como para la comprensión del debate constituyente de 1978 y las cláusulas «interna- 
Dicho lo cual, el Título I de la Constitución Española de 1978 (CE) establece el conocido mandato interpretativo de conformidad con la Declaración Universal de 1948 y los tratados sobre derechos humanos aceptados por España (art. 10.2 CE) para a continuación hacerse eco explícito de la relevancia de las fuentes internacionales en el ámbito de la doble nacionalidad (art. 11.3 CE), la extranjería (art. 13.1 CE), la extradición (art. 13.3 CE), o la protección de la infancia (art. 39.4 CE); se completa la remisión a los estándares internacionales de modo implícito en materia de asilo (art. 13.4 CE) y de forma genérica en el terreno de la emigración (art. $42 \mathrm{CE}$ ).

Desde luego, sobre algunas de estas materias u otras conexas (por ejemplo, la relación entre la protección de los trabajadores españoles en el exterior del art. $42 \mathrm{CE}^{6}$ y la libertad de circulación y residencia del art. 19 CE) se criticó la ausencia de remisión al Derecho internacional ${ }^{7}$. Y, obvio es decirlo, al margen de la natural asunción de normas convencionales o internacionales en el terreno de los derechos humanos, la incorporación de normas de Derecho derivado o secundario de la Unión Europea (UE) dota de dinamismo y cotidianeidad a nuestro ordenamiento interno, en terrenos concernientes tanto al espacio de libertad, seguridad y justicia (como la extradición o el asilo) como al modelo socio-económico (piénsese en el debate actual en torno al desplazamiento de trabajadores en el marco de una prestación de servicios y la problemática del dumping social).

Por su lado, el Título II atribuye al Rey, como Jefe del Estado, la más alta representación del Estado español «en las relaciones internacionales» (art. 56.1 CE), así como las funciones de acreditación activa y pasiva de representantes diplomáticos y extranjeros, de prestación del consentimiento del Estado para obligarse internacionalmente por medio de tratados, o de declaración de guerra y consecución de la paz previa autorización de las Cortes Generales (art. 63 CE).

Ciertamente, el Título III de la Norma Suprema reviste una posición central, pues tras prever los elementos «exteriores» que quedan excluidos de algunas modalidades o fases del procedimiento legislativo en su capítulo I (se exceptúan las «cuestiones internacionales» de la delegación en las Comisiones Legislativas Permanentes en el art. 75.3 CE) o en su capítulo II (se excluye la iniciativa legislativa popular en materias de «carácter internacional» en el art. $87.3 \mathrm{CE}$ ), lleva por rúbrica en su capítulo III «De los tratados internacionales» y se ocupa de la intervención de las Cortes Genera-

cionales» de nuestra Constitución vigente, me remito al excelente trabajo (que sigo en el presente apartado) de Remiro Brotóns, A.: «La Constitución y el Derecho internacional», en Álvarez Conde, E. (Coord.): Administraciones Públicas y Constitución. Reflexiones sobre el XX Aniversario de la Constitución Española de 1978, Madrid, INAP, 1998, pp. 227-257.

5 Por todos, Saiz Arnaiz, A.: La apertura constitucional al Derecho internacional y europeo de los derechos bumanos. El artículo 10.2 de la Constitución española, Madrid, Consejo General del Poder Judicial, 1999.

${ }^{6}$ Esa ineludible internacionalización la ha advertido Alzaga Villaamil, O.: Comentario sistemático a la Constitución española de 1978, Marcial Pons, Madrid, 2017, p. 247: «los objetivos del art. 42, primer inciso, dependen, en buena medida, de la voluntad de terceras potencias soberanas».

7 Esa omisión, con relación al art. 19 CE, la criticó Pérez VerA, E.: Derecho internacional privado. Parte especial, Madrid, Tecnos, 1980, p. 126. 
les en la conclusión de los tratados (arts. 93 y 94 CE), de la sintonía de estos con la Constitución (art. 95) y del régimen de observancia (mandato aplicativo conforme a la regla Pacta sunt servanda), enmienda y modificación, nulidad, terminación y suspensión de los tratados constitucionalizando, como es lógico, lo dispuesto en la Convención de Viena sobre el Derecho de los Tratados de $1969^{8}$ (art. 96 CE). Lo cierto es que, al margen de las disposiciones de los Reglamentos del Congreso y del Senado o de la Ley Orgánica del Tribunal Constitucional (con respecto a la intervención de las Cámaras en el procedimiento de asunción y vigencia de los tratados, o del control de éstos por parte de la Jurisdicción Constitucional, respectivamente), se ha demorado un enfoque más detallado de la materia, en pretendida línea con la Convención de Viena, mediante la Ley 25/2014, de 27 de noviembre, de Tratados y otros Acuerdos Internacionales.

A continuación, el Título IV atribuye al Gobierno, entre sus funciones, la dirección de la política exterior (art. 97 CE). Seguidamente, el Título VII sobre «Economía y Hacienda» incluye la única referencia explícita a la UE en el art. 135 CE tras la polémica reforma «exprés» de 2011 introduciendo el principio de equilibrio presupuestario. Curiosamente, tanto ésta, como la primera reforma constitucional (la del art. 13.2 CE) ha venido de la mano del peso ejercido por los compromisos internacionales, y más precisamente europeos, aspecto sobre el que se volverá en el apartado 8.1, infra.

Por último, el Título VIII completa la impregnación internacional del Texto Constitucional de 1978 al acometer la distribución competencial entre el Estado y las Comunidades Autónomas (art. 149.1) y establecer la exclusividad estatal en materia de «relaciones internacionales» $\left(1 .^{\mathrm{a}}\right)$. De todos modos, las demás materias guardan una conexión clara con la proyección exterior del Estado, ora explícita (por ejemplo, nacionalidad, inmigración, extranjería y derecho de asilo: 2. ; régimen aduanero y arancelario o comercio exterior: $10{ }^{a}$ ) ora implícitamente por tratarse de materias relacionadas con el núcleo duro de la soberanía que el Estado debe afirmar en el interior y frente al exterior (piénsese en defensa y fuerzas armadas: 4. ; o en administración de justicia: $5 .^{a}$ ). El caso es que, paradójicamente, la interpretación de dichas materias ha podido generar una impresión de mayor apertura regional hacia el exterior en supuestos de exclusividad y, en contraste, una percepción centralizadora en materias aparentemente más idóneas para la acción autonómica (al respecto se reflexionará en el apartado 8.2, infra).

Pues bien, la vacilante postura constituyente que condujo a la plasmación y la proyección, explícita o implícita, precisa o genérica, de los reseñados estándares internacionales en la Carta Magna de 1978, debe entenderse inexorablemente superada por la necesaria coherencia con la realidad del Estado supranacional e internacionalmente integrado. En efecto, «si ya desde el siglo XVIII se especuló con el federalismo internacional» en la medida en que «la paz no puede asentarse ni afirmarse como no sea mediante un pacto entre los pueblos conforme al Derecho de gentes», lo bien

${ }^{8}$ Instrumento de adhesión de 2 de mayo de 1972 (BOE n. ${ }^{\circ}$ 142, de 13 de junio de 1980).

(C) UNED. Revista de Derecho Politico 
cierto es «que la realidad actual es muy diferente a la de entonces, pero en el sentido de que abunda todavía más en la interdependencia de las naciones» ${ }^{9}$. Ese espíritu, finalmente, siquiera de modo lacónico, se hallaba presente en la voluntad de la Nación española, proclamada en el Preámbulo constitucional de 1978, de «colaborar en el fortalecimiento de unas relaciones pacíficas y de eficaz cooperación entre todos los pueblos de la Tierra».

Con las premisas expuestas, la presente contribución se verá completada en los primeros apartados reflexionando acerca de la forma fluctuante en que la influencia de los estándares internacionales ha sido secundada por la posición igualmente vacilante de la jurisdicción constitucional española (apartado 2) o se ha visto compensada a la baja (con distanciamiento frente a las normas convencionales generales) o al alza (con entusiasmo a veces desmedido hacia la norma comunitaria europea) por parte de la doctrina constitucionalista (apartado 3). Pese a todo, en el bloque central del trabajo se pone críticamente el énfasis en el potencial juego de esas cláusulas constitucionales de apertura internacional en materia de derechos humanos (apartado 4), en el todavía inexplorado impacto de los tratados en el sistema constitucional de fuentes (apartado 5), en la proyección asimismo favorable de los cánones internacionales en la parte dogmática (apartado 6) y en la parte organizativa de la Constitución (apartado 7), así como en el alcance positivo de esos mismos cánones en la defensa ordinaria y extraordinaria del orden constitucional y el papel jugado en ello por la Universidad (apartado 8). El estudio quedaría incompleto sin unos ulteriores apuntes sobre el peso recíproco que proyectan las normas constitucionales sobre los instrumentos internacionales (apartado 9), poniéndose colofón justamente con unas reflexiones finales sobre la retroalimentación de los estándares internacionales y constitucionales (apartado 10).

\section{CUESTIONAMIENTOS SUCESIVOS: EL PESO DEL ENCLAUSTRAMIENTO DE LA JURISDICCIÓN CONSTITUCIONAL ANTE LOS PARÁMETROS INTERNACIONALES}

Comoquiera que la posición de nuestra jurisdicción constitucional en cuanto a la asunción sustancial de estándares internacionales va a ser objeto de atención particularizada en su vertiente de mandato interpretativo del art. 10.2 CE y en su dimensión de mandato aplicativo ex art. 96 CE (apartados 4 y 5, respectivamente, infra), es pertinente ahora efectuar un somero examen de la actitud de enclaustramiento del máximo intérprete de la Carta Manga bajo el ángulo de determinados aspectos procesales atinentes a una frustrada o retardada internacionalización del control de constitucionalidad.

9 Torres del Moral, A.: Estado de Derecho y democracia de partidos, Madrid, Universidad Complutense, 2010, 3. a ed., especialmente lección 5. ( «El Estado supranacional e internacionalmente integrado»), p. 110. 
Así, un primer signo de cerrazón hacia los parámetros internacionales procede de la exclusión de éstos del llamado «bloque de constitucionalidad» ${ }^{10}$, un categoría importada con mejor o peor fortuna de Francia: el caso es que dicho bloque no queda integrado por las mismas fuentes normativas en el país vecino y en España, ni tampoco media un consenso en la doctrina española en torno a sus componentes. En nuestro caso, dicho bloque alberga normas que juegan, a semejanza de la Constitución, como parámetro de constitucionalidad de las leyes y disposiciones con fuerza de ley, encontrándose su soporte o base habilitante — según el propio TC — en el art. 28.1 LOTC $^{11}$. En esta línea, nuestra jurisdicción constitucional ha incluido como parte de ese bloque los Estatutos de Autonomía o las leyes de reparto competencial previstas en el artículo 150 de la Constitución ${ }^{12}$, los reglamentos parlamentarios ${ }^{13}$ y algunas leyes orgánicas (relativas a la financiación de las Comunidades Autónomas, al Poder Judicial, al régimen electoral general o a las fuerzas y cuerpos de seguridad $)^{14}$.

Ello no significa que haya quedado cerrado el posible círculo de normas integrantes de dicho bloque, como lo demuestra que algunos autores alberguen en él con un criterio excesivamente laxo toda la legislación orgánica ${ }^{15}$, mientras otros no comparten dicho criterio ${ }^{16}$. Hasta tal punto es polémica esta cuestión que, para ensanchar ese bloque, desde una postura más flexible se ha llegado a formular la propuesta del «bloque constitucional», extensible al Derecho primario u originario de la $\mathrm{UE}^{17} \mathrm{y}$, más ampliamente, al Derecho secundario o derivado ${ }^{18}$. Bien es verdad que tanto en Francia como en España se excluye del bloque de constitucionalidad los tratados internacionales clásicos y las normas de la $\mathrm{UE}^{19}$, pero semejante exclusión ha sido

10 Puede acudirse a la obra de Favoreu, L., y Rubio Llorente, F.: El bloque de constitucionalidad (Symposium franco-español de Derecho Constitucional), Madrid, Civitas, 1991. Véase asimismo RuBIo LloRENTE, F.: «El bloque de constitucionalidad», Revista Española de Derecho Constitucional, n. ${ }^{\circ}$ 27, septiembre-diciembre 1989.

11 Por todas, STC 137/1986, FJ 4.․

12 Por ejemplo, STC 149/1991, FJ 1.․

13 Verbigracia, STC 99/1987, FJ 1.‥

${ }_{14}$ Así, SSTC 181/1988 (FJ 3..$^{\circ}$ ), 56/1990 (FJ 2. ${ }^{\circ}$ ), 154/1988 (FJ 3. ${ }^{\circ}$ ), y 25/1993 (FJ 1..$^{\circ}$ ), respectivamente.

15 Vid. Fernandez Rodríguez, T.R.: Las leyes orgánicas y el bloque de constitucionalidad, Madrid, Civitas, 1981.

${ }^{16}$ Desde esta perspectiva, el bloque de la constitucionalidad quedaría reservado al núcleo distribuidor de competencias entre Estado y Comunidades Autónomas, pero excluyendo las leyes orgánicas: así, Aparicio Pérez, M.A.: «Algunas consideraciones sobre la Justicia Constitucional y el Poder Judicial», Revista Jurídica de Catalunya, n. ${ }^{\circ} 4,1983$, p. 169.

17 Requejo Rodriguez, P.: «Bloque constitucional y Unión Europea», en Jáuregui Bereciartu, G., y Ugartemendía Eceizabarrena, J.I. (Coords.): Derecho Constitucional Europeo, Valencia, Tirant lo Blanch, pp. 319-340.

18 Balaguer Callejón, F.: «La Constitución y las fuentes del Derecho», en Álvarez Conde, E. (Coord.): Administraciones Públicas y Constitución. Reflexiones sobre el XX Aniversario de la Constitución Española de 1978, Madrid, INAP, 1998, p. 178.

19 Por todas, Decisión 93-335 DC del Consejo Constitucional; así como Favoreu, L.: «El bloque de constitucionalidad», Revista del Centro de Estudios Constitucionales, n. ${ }^{\circ}$ 5, enero-marzo 1990, pp. 45-68. 
criticada con sólidos argumentos en Francia $^{20}$, así como en Italia ${ }^{21}$; una crítica que comparto con respecto a España, en donde el TC se ha mostrado vacilante ${ }^{22}$.

Un segundo signo de enclaustramiento tiene que ver con la asunción del problemático control sucesivo de constitucionalidad de los tratados. Como es conocido, nuestra Carta Magna sólo contempla expresamente el control previo de los tratados en el art. 95, lo cual es lógico y coherente con la correcta articulación de las normas de producción nacional e internacional. Dicho de otro modo, se trata de evitar un conflicto de normas que, con carácter adicional, comporte responsabilidad internacional del Estado.

Ahora bien, en las dos ocasiones en las que, hasta la fecha, ha sido activado ese control preventivo del art. 95 CE (Declaraciones 1/1992, de 1 de julio, y 1/2004, de 13 de diciembre), el Alto Tribunal ha evocado la posibilidad de ejercer asimismo el control de constitucionalidad sucesivo de los tratados so pretexto de asegurar la supremacía de la Carta Magna y aunque ello pueda implicar responsabilidad internacional y perturbación para la política exterior y las relaciones internacionales del Estado (FJ 1 de ambas Declaraciones). Formulada en tales términos y con semejante alcance, esa posibilidad puede revelarse incluso inconstitucional, por contraria básicamente al art. 96 CE cuando constitucionaliza — como ya esgrimí - la solución de la Convención de Viena sobre el Derecho de los Tratados de $1969^{23}$. Solamente el hecho de sugerir la justificación de una responsabilidad internacional resulta anómalo ${ }^{24}$, escudándose en una especie de estoppel redivivo ${ }^{25}$.

20 Rousseau, D.: «L'intégration de la Convention européenne des droits de l'homme au bloc de constitutionnalité», en Rousseau, D., y Sudre, F. (Dirs.): Conseil constitutionnel et Cour européenne des droits de l'bomme, Nancy, éd. STH, 1990.

${ }^{21}$ Celotto, A.: «Italia», en De Miguel, J., y Tajaura Tejada, J. (Coords.): Justicia Constitucional y Unión Europea, Madrid, CEPC, 2008, p. 233: «en el caso de que una ley nacional, estatal o regional, viole disposiciones comunitarias, la incompatibilidad comunitaria, determina también la inconstitucionalidad».

22 A título de ejemplo, en la STC 36/1991, de 14 de febrero, FJ 5 (a la que se remite la posterior STC 236/2007, FJ 5) se sostiene que el art. 10.2 CE «no da rango constitucional a los derechos y libertades internacionalmente proclamados en cuanto no estén también consagrados por nuestra propia Constitución, pero obliga a interpretar los correspondientes preceptos de ésta de acuerdo con el contenido de dichos Tratados o Convenios, de modo que en la práctica ese contenido se convierte en cierto modo en el contenido constitucionalmente declarado de los derechos y libertades que enuncia el capítulo segundo del título I de nuestra Constitución».

${ }^{23}$ Jimena QuesadA, L.: «La inconstitucionalidad del control de constitucionalidad sucesivo de los tratados internacionales (crítica a la postura mantenida por el Tribunal constitucional español)», en PÉREZ Tremps, P. (Coord.): La reforma del Tribunal Constitucional, Valencia, Tirant lo Blanch, 2007, pp. 419-439.

${ }^{24}$ En el marco de la STC 38/2007, de 15 de febrero, se llegó a suscitar de forma tenue la inconstitucionalidad del art. 27.2.c) LOTC por parte de la Abogacía del Estado, sin que el TC entrara de lleno en la cuestión y, al contrario, sí avalara indirectamente dicha constitucionalidad, no despejando dudas sobre el alcance de una eventual declaración de inconstitucionalidad del tratado sometido a su control (FJ 3). Véanse también SSTC 80 a 90/2007, todas ellas de 19 de abril de 2007.

25 Véase, mutatis mutandis, para el caso italiano, las reflexiones de GUARINO, G.: «Corte costituzionale e Diritto internazionale: il ritorno dell'estoppel?», Consulta Online, 4 de diciembre de 2014, http:// 
Consecuentemente, para salvar la constitucionalidad de ese control sucesivo de los tratados internacionales y no incurrir en responsabilidad internacional, matizando al tiempo la jurisprudencia del TC y corrigiendo las anomalías de la LOTC, debería entenderse ciertamente que el TC no estaría operando como mero órgano consultivo (como dijo en la Declaración 1/1992, de 1 de julio), puesto que no nos hallaríamos ante una simple consulta no vinculante, pero su declaración obligaría a articular el procedimiento de denuncia del tratado en el improbable supuesto (a tenor del control previo que ya se efectúa ante el Consejo de $\operatorname{Estado}^{26}$ y la posibilidad no utilizada del art. $95 \mathrm{CE}$ ) de declarar su inconstitucionalidad sobrevenida.

En fin, el tercer signo de déficit de apertura de nuestra jurisdicción constitucional guarda relación con la tardía activación de la cuestión prejudicial (art. 267 TFUE) ante el TJUE. Como se recordará, en la primera planteada por el TC (mediante el Auto 86/2011, de 9 de junio $)^{27}$, éste apelaba sencilla y acertadamente a la base habilitante del art. 267 TFUE (FJ 4). No se trata ahora de abordar la controversia sobre la oportunidad y el alcance sustancial de dicha cuestión prejudicial, por lo que no entraré en los pormenores del modo en que se ha articulado la tutela multinivel de derechos a la luz del art. 53 de la Carta de los Derechos Fundamentales de la UE (CDFUE) y del principio favor libertatis ${ }^{28}$. Bastará ahora con aplaudir ese planteamiento en el plano procedimental ${ }^{29}$, lamentando que nuestra jurisdicción constitucional no se incorporara antes a ese diálogo judicial, como bien criticó Pablo Pérez Tremps en su voto particular a dicho Auto 86/2011.

\section{CUESTIONARIOS ULTERIORES: LA PRESENCIA DE UN CONSTITUCIONALISMO ENSIMISMADO CON RESPECTO A LAS FUENTES INTERNACIONALES EN GENERAL Y RELATIVAMENTE ENTUSIASMADO CON RELACIÓN A LAS FUENTES EUROPEAS EN PARTICULAR}

Tengo la impresión, tras los cuarenta años de vigencia de la Carta Magna de 1978, de que el tratamiento constitucionalista de las fuentes internacionales ha conocido, incluso a pesar de las cláusulas de apertura internacional presentes en aquélla, un cierto ensimismamiento que no resulta coherente con la mencionada creciente reali-

\footnotetext{
www.giurcost.org/studi/guarino7.pdf (visitado el 9 de septiembre de 2016), p. 9: «Pretender, por tanto, como hace nuestra Corte, que el derecho de soberanía prevalezca sobre todo (una especie de estoppel redivivo) equivale a afirmar que nuestro específico sistema jurídico es, en su caso, universal: es éste el que decide si y qué normas del ordenamiento internacional aplicar».

${ }^{26}$ Véanse arts. 21 y 22 de la Ley Orgánica 3/1980, de 22 de abril, del Consejo de Estado.

${ }^{27}$ El Auto del TC tuvo su respuesta en la STJUE de 26 de febrero de 2013 (asunto C-399/11, Melloni).

${ }^{28}$ Véanse los votos particulares a la STC 26/2014, de 13 de febrero de 2014 (asunto Melloni).

29 Para enmarcar esta problemática, Vírgala Foruria, E.: «Tribunal Constitucional, recurso de amparo y Unión Europea», en el colectivo La protección de los derechos fundamentales en la Unión Europea (Coord. Corcuera Atienza, J.), Madrid/Oñati, Dykinson/Instituto de Sociología Jurídica, 2002.
} 
dad del Estado supranacional e internacionalmente integrado; de tal suerte que, por un lado, es decisivo el papel que sigue jugando el Estado nacional al no percibirse la emergencia de un «Estado mundial soberano»y, por ende, al legitimar aquél su acción exterior de éste mediante constituciones democráticas y, «por otro lado, son los propios Estados los que impulsan (o al menos, ellos lo hacen también) la ampliación progresiva del Derecho internacional» ${ }^{30}$.

Podría constatarse, incluso, que ha habido una dejadez del constitucionalista, paralelo al del constituyente, con relación al tratamiento de las normas generales del Derecho internacional; un descuido incidentalmente salvado por la ineludible interpelación de los arts. 10.2 y $96.1 \mathrm{CE}^{31}$, que sin embargo no parecen haber sido convenientemente explotados en todo su potencial (remisión al análisis particularizado en los apartados 4 y 5, infra). Incluso el tratado más emblemático del Consejo de Europa (el CEDH) y su buque insignia (el TEDH) fueron objeto de negligencia durante años por parte de la doctrina constitucionalista. Y no deja de ser sintomático que no se haya insistido lo suficiente en acometer en la legislación interna el procedimiento de ejecución de las sentencias del $\mathrm{TEDH}^{32}$, caminando a veces a golpe de resolución controvertida y mediática ${ }^{33}$. La popularidad del CEDH, que tendría que ir de suyo ${ }^{34}$, ha ido consolidándose como un creciente e ilusionante campo de análisis entre los constitucionalistas, a costa de otros instrumentos del Consejo de Europa como el natural complemento de la Carta Social Europea.

No constituye el objeto del presente análisis paliar, y ni siquiera reducir, ese déficit de tratamiento doctrinal. Tarea demasiado pretenciosa. Basta señalar, en esta sede, la referida constatación de dejadez, descuido o negligencia, que ha afectado

30 Torres del Moral, A.: Estado de Derecho y democracia de partidos, op.cit., p. 111.

31 Valga, mutatis mutandis, la apreciación de Remiro Brotóns, A.: op. cit., p. 232.: «La ignorancia de las normas generales del Derecho Internacional como bloque no ha impedido que, casi por accidente, la Constitución haya atribuido relevancia a algunas de tales normas en dos áreas concretas: una, la de los derechos y libertades fundamentales reconocidos en la Constitución, cuyos preceptos han de interpretarse, en efecto (art. 10.2), "de conformidad con la Declaración Universal de Derechos Humanos" de 1948, donde se integra un conjunto de normas internacionales imperativas; otra, la de la modificación, suspensión y terminación de los tratados, cuyas disposiciones "sólo podrán ser derogadas o suspendidas en la forma prevista en los propios tratados o de acuerdo con las normas generales del Derecho Internacional" (art. 96.1), lo que debería garantizar — bajo la tutela del Tribunal Constitucional—, la protección del ius cogens internacional por lo menos frente a los tratados en que sea parte España».

32 Interesa la lectura del Informe del Consejo de Estado sobre la inserción del Derecho europeo en el ordenamiento español, de 14 de febrero de 2008, y en particular sobre la ejecución de las sentencias del TEDH en el ordenamiento español y en otros comparados, pp. 293-323.

33 Vid. STEDH (Gran Sala) Del Río Prada c. España de 21 de octubre de 2013, sobre la «doctrina Parot».

${ }^{4}$ La razón es muy simple, como acertadamente ha hecho notar Freixes SANJuÁN, T.: «La Constitución y el sistema de derechos fundamentales y libertades públicas», en Álvarez CondE, E. (Coord.): Administraciones Públicas y Constitución. Reflexiones sobre el XX Aniversario de la Constitución Española de 1978, Madrid, INAP, 1998, p. 164: «Ya señalé en su momento que la violación de los derechos fundamentales declarada por el Tribunal de Estrasburgo, cuando se tratara de derechos del Convenio que también habían sido reconocidos por la Constitución de 1978, constituía una violación de la Constitución que los órganos internos estaban obligados a reparar». 
tanto a las posibles cuestiones constitucionales suscitadas por la celebración de los tratados (la tramitación de la concesión de la autorización en cada Cámara de las Cortes Generales y la posibilidad de enmiendas, las discrepancias entre ambas Cámaras, etc.), como al persistente debate sobre la posición de los tratados en el sistema constitucional de fuentes.

La reflexión anterior sobre las normas convencionales generales resulta en buena medida trasladable al Derecho de la $\mathrm{UE}^{35}$. En efecto, más allá del debate academicista manifestado (de manera simplista) en el reparto de la docencia sobre dicha materia entre diversas áreas (Derecho administrativo, Derecho constitucional y Derecho internacional público), pareciere como si la necesaria y resuelta atención al Derecho comunitario europeo hubiera necesitado del input de esa especie de operación de marketing consistente en llamar «Constitución europea» a la gran reforma posterior al Tratado de Niza que se saldó con el fallido Tratado por el que se establecía una Constitución para Europa de $2004^{36}$.

$\mathrm{Si}$ acaso, es justo reconocer que el Tratado constitucional perseguía, entre sus loables objetivos, la simplificación de las fuentes del Derecho de la UE, lo que lamentablemente quedó frustrado con el conjunto del Tratado tras los referendos negativos en Francia y Holanda. Esa simplificación no hubiera sido nada desdeñable, pues entre la panoplia de normas de Derecho primario y secundario se han ubicado categorías como las normas de Derecho complementario ${ }^{37}$, o han irrumpido técnicas de comunitarización de ámbitos iniciales de cooperación intergubernamental como el acervo de Schengen que han alterado la base habilitante constitucional nacional ${ }^{38}$.

En cualquier caso, el entusiasmo con el que se recibía en el constitucionalismo semejante operación de marketing constitucional europeo a principios de los años 2000 ya había venido animado por la propia novedad de la integración de España en las

35 Semejante paralelismo ha sido lógicamente recalcado por MANGas MarTín, A.: «La Constitución y el Derecho comunitario», en Álvarez Conde, E. (Coord.): Administraciones Públicas y Constitución. Reflexiones sobre el XX Aniversario de la Constitución Española de 1978, Madrid, INAP, 1998, p. 181: «Las relaciones entre el Derecho español y el Derecho comunitario han venido facilitadas por una tradición legal, jurisprudencial y doctrinal favorable a la primacía y a la eficacia de los Tratados internacionales de los que España es parte. Esa actitud, que hunde sus raíces en la Escuela Española del Derecho de Gentes (la Escuela de Salamanca), revela, desde una posición monista, una necesidad de coherencia en la conducta interna y externa del Estado. Los órganos del Estado en su actividad normativa, ya se interna o externa, general el Derecho (interno e internacional) y, por coherencia, no deben contribuir a formar normas incompatibles».

36 Así la caracterizan, por referencia al llamado proceso de «constitucionalización» de Europa y al más concreto conducente a la Carta de los Derechos Fundamentales, Jimena Quesada, L., y Alegre Martínez, M.A.: Fundamentos Constitucionales de la Unión Europea, Madrid, Biblioteca Nueva, 2006, pp. 26 y 274.

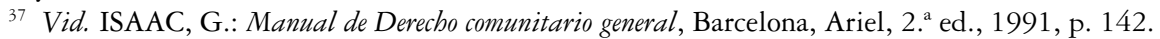

38 La base habilitante mediante la que se avalaban los efectos del espacio normativo Schengen en España pasó, de haber sido ratificado en virtud del art. $94 \mathrm{CE}$, a venir fundamentado en el art. $93 \mathrm{CE}$ : Donaire Villa, F.J.: La Constitución y el acervo de Schengen, Valencia, Tirant lo Blanch/Instituto de Derecho Público Comparado Manuel García-Pelayo, 2002, en especial, pp. 91 y ss. 
Comunidades Europeas en 1986. Todo un reto ante un enmarañado conjunto normativo desconocido (incluso el acceso a las primeras cátedras Jean-Monnet para promover la enseñanza del Derecho comunitario se configuraba oscuro o poco transparente) que, no obstante, generaba un grado imponderable de optimismo asociado en buena medida a esos novedosos principios de primacía y efecto directo (sentados por la jurisprudencia del Tribunal de Justicia desde los años 1960) de un ordenamiento catalogado como de tertium genus entre el Derecho internacional clásico y el Derecho nacional.

Por consiguiente, la doctrina constitucionalista debía cesar en su actitud acomodaticia para una correcta aprehensión del Derecho comunitario europeo que, a su vez, comportaba la responsabilidad de enseñarlo con solvencia a los futuros operadores jurídicos ${ }^{39}$. En otras palabras, la enseñanza del Derecho constitucional se veía sustancialmente transformada por el nuevo ordenamiento europeo. La tarea no era ni es sencilla, puesto que la propia dinámica evolutiva de la integración europea ha ido ensanchando el entramado normativo comunitario que, a los ojos del constitucionalista, ha perfilado un movimiento contrapuesto: de un lado, la vis atractiva de las normas de la UE ha provocado un acentuado descuido en el tratamiento constitucional de las normas generales del Derecho internacional y, de otro lado, el propio sistema jurídico de la UE ha producido otras categorías normativas que han planteado interrogantes imprevistos (en clave de déficit democrático y de legitimidad) en el funcionamiento interno del edificio comunitario.

Los efectos de ese doble movimiento sobre los aplicadores del Derechos serán objeto de atención más adelante (apartado 5, infra). Por el momento, resulta suficiente hacer hincapié en la distorsión que esas nuevas categorías normativas, que responden en algunos supuestos a actuaciones de la UE al margen de su propio Derecho ${ }^{40}$, provocan asimismo en el plano vertical (con afectación al orden constitucional de los Estados miembros) y horizontal (con incidencia en el orden internacional): piénsese en el acuerdo de la UE con Turquía sobre personas refugiadas y la contradicción con la normativa universal en la materia, con la jurisprudencia del TEDH o, peor aún, con los propios Tratados comunitarios ${ }^{41}$; repárese asimismo en los instrumentos nor-

39 Jiménez Asensio, R.: El constitucionalismo, Oñati, IVAP, 2001, p. 150:

40 Sarmiento, D.: El Derecho de la Unión Europea, Madrid, Marcial Pons, 2016, p. 64: el citado autor trae a colación, como aval de esas actuaciones, la STJUE Pringle de 27 de noviembre de 2012 (asunto C-370/12).

41 Véase el Acuerdo entre Turquía y la UE de 18 de marzo de 2016, oficialmente denominado Declaración. Dicha «Declaración», pretendidamente política, recogería realmente un Tratado internacional que no ha respetado los cauces previstos por los art. 216 y siguientes del TFUE, por cuanto al acordarlo los Jefes de Estado y de Gobierno en el seno del Consejo de Europeo se ha eludido la vía negociadora y aprobatoria que recae según dichas disposiciones en la Comisión y el Consejo, además del dictamen conforme o consentimiento del PE cuando tenga (como es el caso) «repercusiones presupuestarias importantes para la UE» [artículo 218.6.a.iv) TFUE]; y, sobre todo, se ha sustraído al previo dictamen vinculante del TJUE, además de dificultar ante éste el control posterior: crítica recogida en DEN HEIJER, M., RijPMA, J.J., y SPIJKERBOER, T.: «Coercion, Prohibition, and Great Expectations: The Continuing Failure of the Common European Asylum System», Common Market Law Review, n. ${ }^{\circ}$ 53, 2016, pp. 607-642. 
mativos impulsados por la Troika y las divergencias generadas con los cánones sociales del Consejo de Europa ${ }^{42}$; obsérvese, en fin, el potencial impacto de instrumentos como el reciente Acuerdo de Libre Comercio de la UE con Canadá (CETA, por sus siglas en inglés) ${ }^{43}$, cuya conclusión hubo de acompañarse el 27 de octubre de 2016 de salvaguardias de los estándares mínimos de la OIT mediante un Instrumento Interpretativo conjunto ${ }^{44}$.

\section{LAS CLÁUSULAS CONSTITUCIONALES DE APERTURA INTERNACIONAL: ESPECIAL CONSIDERACIÓN DE LOS INSTRUMENTOS DE DERECHOS HUMANOS}

Sin lugar a dudas, la cláusula de apertura internacional por excelencia en la Carta Magna de 1978 viene dada por el art. 10.2 CE. No es este el espacio para otro ensayo sobre el alcance e impacto de dicha disposición constitucional ${ }^{45}$. Antes bien, entiendo más útil y adecuado a los efectos de la presente contribución efectuar una crítica sobre el triple efecto distorsionador que he percibido en la exégesis del art. 10.2 CE llevada a cabo por nuestro TC: el primero, ya anticipado (apartado 2, supra), tiene que ver con el juego disfuncional de la noción de bloque de constitucionalidad manejada por el TC; el segundo se refiere a la artificial disociación de las fases de interpretación y de aplicación de las normas internacionales sobre derechos humanos; y el tercero, consecuencia de lo anterior, el difícil diálogo de la jurisdicción nacional ordinaria con la constitucional y con la internacional.

En cuanto a lo primero, tras explicar el significado de la «interpretación» a la que alude el artículo 10.2 CE y señalar que, en el plano teórico, dicha disposición constitucional «no convierte a tales tratados y acuerdos internacionales en canon autónomo de validez de las normas y actos de los poderes públicos desde la perspectiva de los derechos fundamentales» e incidir en que «si así fuera, sobraría la proclamación

${ }^{4}$ Véase Resolución del Parlamento Europeo, de 13 de marzo de 2014, sobre los aspectos laborales y sociales del papel y las actividades de la Troika (BCE, Comisión y FMI) en relación con los países de la zona del euro sujetos a un programa (2014/2007(INI)); así como STANGOS, P.: «Les répercussions juridiques sur l'Union européenne des décisions du Comité européen des Droits sociaux relatives aux mesures d'austérité de la Grèce», Revue Trimestrielle des Droits de l'Homme, n. 4, 2015, pp. 909-939.

${ }^{4}$ Comprehensive Economic and Trade Agreement/Acuerdo Económico y General Global entre Canadá, la UE y sus Estados miembros.

44 Véase el punto 8 de dicho Instrumento Interpretativo, bajo la rúbrica «protección laboral». Ello es coherente con el art. 53 de la Convención de Viena de 1969, que prevé la nulidad de «todo tratado que, en el momento de su celebración. esté en oposición con una norma imperativa de derecho internacional general» (ius cogens).

${ }^{45}$ De nuevo, Saiz Arnaiz, A.: op.cit.; así como Aparicio Pérez, M.A.: «La cláusula interpretativa del artículo 10.2 de la Constitución española, como cláusula de integración y apertura constitucional a los derechos fundamentales», Jueces para la democracia, n. ${ }^{\circ}$ 6, 1989, o DE CARreras SERra, F.: «Función y alcance del artículo 10.2 de la Constitución», Revista Española de Derecho Constitucional, n. ${ }^{\circ}$ 60, 2000. 
constitucional de tales derechos», se ve obligado nuestro TC a matizar el alcance de esa explicación añadiendo que son «los textos y acuerdos internacionales del artículo 10.2 una fuente interpretativa que contribuye a la mejor identificación del contenido de los derechos cuya tutela se pide a este Tribunal Constitucional» (por todas, STC 236/2007, de 7 de noviembre, FJ 5).

Así las cosas, esta misma STC 236/2007 (FJ 6) muestra claramente que las normas internacionales y la jurisprudencia internacional integran y perfeccionan materialmente nuestro bloque de constitucionalidad ${ }^{46}$, pues el núcleo de la ratio decidendi a la hora de enjuiciar la Ley Orgánica 8/2000, de 22 de diciembre (de modificación en sentido restrictivo de la Ley Orgánica 4/2000, de 11 de enero, de 11 de enero, sobre derechos y libertades de los extranjeros en España y su integración social), se basa explícitamente en el canon supranacional, citándose diversos preceptos de la Declaración Universal de Derechos Humanos, del PIDCP y del $\mathrm{CEDH}$, así como diversos pronunciamientos del TEDH. En síntesis, el TC no parece mostrarse siempre consecuente con su postura, incurriendo en ocasiones en la paradoja de afirmar la exclusión de las normas internacionales del bloque de constitucionalidad para, a renglón seguido, utilizar el canon internacional como canon de constitucionalidad.

En conexión con lo precedente, el segundo efecto distorsionador apunta al riesgo de privar al mandato interpretativo del art. 10.2 CE de su condición de regla hermenéutica de aplicación preferente. García de Enterría lo adelantaba ya, por referencia al CEDH, tras el primer decenio de recorrido de nuestra Carta Magna, al subrayar que «el Derecho constitucional español conoce un caso absolutamente singular de valor constitucional directo del Convenio Europeo que resulta del artículo 10.2 de la Constitución de 1978», arguyendo que «con independencia de las razones que llevaran a establecer una cláusula de este tipo, explicable únicamente por circunstancias singulares aparecidas en el momento de la elaboración de la Constitución española, está claro que la misma ha introducido en nuestro sistema constitucional una regla primordial de aplicación», en la medida en que «los instrumentos internacionales de este tipo se convierten en un criterio para la hermenéutica de la Constitución nacional» ${ }^{47}$.

Lo anterior sin perjuicio de que el art. 10.2 CE no prevea «su eficacia directa como normas internas» de esos tratados o acuerdos internacionales, eficacia que — como es lógico — viene atribuida únicamente a los tratados que han sido ratificados por España, según otro artículo de la Constitución, el artículo $96{ }^{48}$. De hecho, y al margen

46 Vid. Jimena Quesada, L.: «La vinculación del juez a la jurisprudencia internacional», en REVENGA SÁNCHEZ, M. (Coord.): El Poder Judicial, Valencia, Tirant lo Blanch, 2009, p. 525.

47 GARCÍA DE ENTERRÍA, E.: «Valeur de la jurisprudence de la Cour européenne des Droits de l'Homme en droit espagnol», Protecting Human Rights: The European Dimension/Protection des droits de l'homme: la dimension européenne, Studies in honour of/Mélanges en honneur de Gérard J. Wiarda, Strasbourg, Carl Heymanns Verlag KG, 1988, p. 222.

${ }^{48}$ Ibidem. 
de la Declaración Universal (directa y explícitamente mencionada en el art.10.2), no parece razonable prescindir del juego combinado del art. 10.2 con el art. 96.1 CE. Por tal motivo, seguramente, la entusiasta asunción de la CDFUE precisó, para beneficiarse de los efectos del art. 10.2 CE, de una curiosa técnica de interiorización normativa (art. 2 de la Ley Orgánica 1/2008, de 30 de julio, por la que se autoriza la ratificación por España del Tratado de Lisboa) que se adelantaba a su incorporación mediante la posterior entrada en vigor del Tratado de Lisboa el 1 de diciembre de 2009, y por más que el TC no hubiera escapado a dicho entusiasmo citando la Carta de la UE no sólo antes de su vigencia, sino incluso a su misma proclamación solemne en diciembre de 2000 en Niza ${ }^{49}$.

Con todo, el mayor efecto distorsionador es el tercero, puesto que el problema no radica tanto (como sucede con los dos efectos precedentes) en un paradójico enfoque teórico-doctrinal que no elude los efectos del art. 10.2 CE, sino en una praxis que sí priva de alcance a dicha disposición constitucional al apartarse deliberadamente del canon internacional. Ello ha ocurrido, incomprensiblemente, en el marco de la reseñada STC 236/2007, en cuyo FJ 7 se muestra más proclive a la divergencia que al diálogo al abordar el derecho a la reagrupación familiar, «que no forma parte del contenido del derecho consagrado en el art. 18 CE», y ello «en contraste con» la jurisprudencia del TEDH, que sí incluye tal derecho en el equivalente art. 8 CEDH. Para nuestra jurisdicción constitucional esa equivalencia no mediaría entre el art. $18 \mathrm{CE}$ y el art. $8 \mathrm{CEDH}$, pese a que el art. 10.2 establezca un mandato interpretativo que, no se olvide, se impone igualmente al mismo $\mathrm{TC}^{50}$.

Lo peor, en última instancia, no es la quiebra del diálogo entre el TC y el TEDH en dicha materia, sino que esa falta de sintonía proyecta otro disfuncional impacto al terciar en ese diálogo la jurisdicción nacional ordinaria. Ésta, en los procedimientos que llegan a su conocimiento (sobre todo, en el contexto de expulsiones sustanciadas en el orden contencioso-administrativo), está siendo consecuente con la jurisprudencia del TEDH, lo mismo que se ha producido en el terreno controvertido de las molestias ambientales (especialmente, contaminación acústica), en donde el TC tampoco ha acabado por asumir la jurisprudencia del TEDH (de nuevo, basado en el contraste de las nociones de vida familiar y respeto del domicilio presentes en el art. 8 CEDH y en el art. $18 \mathrm{CE})^{51}$.

49 Vid. STC 292/2000, de 30 de noviembre, FJ 8.

50 El art. 1 LOTC es meridiano al disponer que el Alto Tribunal está sometido a la Constitución y a su Ley Orgánica.

51 Entre otras, SSTC 119/2001, de 24 de mayo; 16/2004, de 23 de febrero; 141/2009, de 15 de junio, o 150/2011, de 29 de septiembre (en esta última resulta del mayor interés el voto particular formulado por Luis Ignacio Ortega Álvarez al que se adhieren Eugeni Gay Montalvo y Elisa Pérez Vera, que sí se alineaba con la jurisprudencia europea). 


\section{LA POSICIÓN CONSTITUCIONAL DE LOS TRATADOS INTERNACIONALES Y EL LLAMADO CONTROL DE CONVENCIONALIDAD}

Tras cuatro décadas de vigencia de nuestra Carta Magna, parece extraño que en la doctrina constitucionalista no se haya alcanzado todavía consenso en torno al valor supralegal de los tratados y a la inescindible consecuencia de llevar a la práctica (mediante el llamado control de convencionalidad) dicho valor mediante la aplicación judicial de la norma internacional con desplazamiento de la norma nacional, señaladamente cuando la primera recoja un estándar más favorable. Al menos, resulta menos preocupante que ya no se siga equiparando ley y tratado (lo que ha dejado zanjado la Ley 25/2014, de 27 de noviembre, de Tratados y otros Acuerdos Internacionales, infra), resistiéndose en cambio la mayoría de la doctrina a terciar en el debate o a aceptar ese control de convencionalidad difuso, reconduciéndolo si acaso a la jurisdicción concentrada del $\mathrm{TC}^{52}$.

Discrepando de ello, estimo que el ordenamiento español ofrece bases constitucionales explícitas que dan indiscutible soporte al control de convencionalidad (y, por añadidura, a la efectividad de la tutela multinivel de los derechos $)^{53}$, especialmente el mandato aplicativo de los tratados (arts. 93 a 96 CE) en conjunción con el mandato interpretativo (art. 10.2 CE) ${ }^{54}$. En este sentido, aunque la Carta Magna de 1978 no hable explícitamente de esa supralegalidad ${ }^{55}$, de su art. 96 se deriva la superioridad y prevalencia de los tratados con respecto a la ley española ${ }^{56} \mathrm{y}$, en todo caso, ese carác-

52 Vid. Canosa Usera, R.: El control de convencionalidad, Madrid, Civitas/Thomson Reuters, 2015.

53 Vid. Jimena QuesADA, L.: Jurisdicción nacional y control de convencionalidad. A propósito del diálogo judicial y la tutela multinivel de derechos, Cizur Menor, Aranzadi, 2013. Más recientemente, y en el mismo sentido, Fondevila Marón, M.: «Control de convencionalidad y tutela multinivel de derechos», Estudios de Deusto, Vol. 65/1, 2017, pp. 347-360.

54 Fernández de Casadevante y Romaní, C., y Jiménez García, F.: El Derecho Internacional de los Derechos Humanos en la Constitución Española: 25 Años de Jurisprudencia Constitucional, Madrid, Thomson/Civitas, 2006, p. 31.

55 De hecho, en lo que atañe al debate constituyente, en los avatares de la Ponencia recuerda G. Peces-Barba Martínez (La elaboración de la Constitución de 1978, Madrid, Centro de Estudios Constitucionales, 1988) la fórmula equilibrada consistente en eliminar la referencia «a la jerarquía superior de los tratados sobre las leyes, y a la vez integrarlos en el Derecho interno» (p. 97). En el mismo sentido, en la tramitación posterior, la enmienda tendente a incluir en el texto constitucional el rango superior de los tratados con respecto a las leyes fue rechazada (véase Constitución española. Trabajos parlamentarios, ed. preparada por F. Sáinz Moreno y M. Herrero de Padura, Madrid, Congreso de los Diputados, 2. ${ }^{\text {e }}$ ed., 1989, tomo I, p. 2590, y tomo IV, p. 4602).

56 Peces-Barba Martínez, G., con Prieto Sanchís, L.: La Constitución Española de 1978. Un estudio de Derecho y Política, Valencia, Fernando Torres Editor, 2. ed., 1984, p. 149: «La interpretación más lógica del precepto [del art. $96 \mathrm{CE}$ ] parece indicar que los tratados internacionales, como normas internas, gozan de un valor jerárquico superior al de las leyes, ya que sólo pueden modificarse según lo establecido en sus cláusulas o de acuerdo con las reglas generales del Derecho internacional, pero no por las leyes internas». Y añaden a pie de página: «Esta conclusión se obtenía más claramente de la primera redacción de la Ponencia, Boletín Oficial de las Cortes de 5 de enero de 1978, cuyo art. 6,1. ${ }^{\circ}$ establecía que los tratados internacionales válidamente celebrados tendrán, una vez publicados, jerarquía superior a la de las leyes». 
ter supralegal se revela indiscutible cuando se trata de tratados sobre derechos humanos [artículo 94.1.c) de la Carta Magna].

Por otro lado, es cierto que en esto último diverge la Carta constitucional española de otras Constituciones extranjeras, como es el caso de la francesa vigente de 1958 (art. 55) ${ }^{57}$. No obstante, el texto final del art. 96 CE, como se decía, recoge esa superioridad aplicativa de los tratados sobre las leyes, en la línea de la Convención de Viena sobre el Derecho de los Tratados de $1969^{58}$. Con tal filosofía, sobre no ser necesario, la Ley 25/2014 de Tratados y otros Acuerdos Internacionales viene a poner negro sobre blanco lo que dispone el reiterado art. $96 \mathrm{CE}$ al establecer explícitamente esa prevalencia. La lógica argumentativa, recapitulando, es sencilla: si se reconoce la prevalencia del tratado sobre la ley, ¿puede tal afirmación quedar en una mera regla teórica? La respuesta sólo puede tener como consecuencia práctica que esa prevalencia comporta la aplicación judicial preferente del tratado sobre la ley.

A mayor abundamiento, y dejando de lado otras figuras afines al control de convencionalidad como la potestad de la jurisdicción ordinaria de pronunciar una extralimitación reglamentaria ${ }^{59}$, la mayor afinidad viene dada por la lógica de los principios de primacía y efecto directo del Derecho de la UE. Si se tiene en mente ese sencillo paralelismo, quedarán superados los injustificados recelos dogmáticos (acusadamente, en la doctrina constitucionalista ${ }^{60}$ ) a la asunción del control de convencionalidad operado por los órganos jurisdiccionales.

De análogo razonamiento se hizo eco, con gran acierto e inspirándose en la experiencia constitucional francesa, el Consejo de Estado español en su Memoria anual de 1997. Decía así el Consejo de Estado: «En las consultas sobre proyectos legislativos el Consejo de Estado sustituye su tradicional examen de legalidad del texto reglamentario por un doble control o examen de constitucionalidad y de "convencionalidad". Estas verificaciones se realizan también en materia reglamentaria, pero en materia legislativa se hace con mayor meticulosidad. También en los aspectos formales y de contenido se observan matices en los Dictámenes, posiblemente por el mayor rigor y mejor

57 Según el art. 55 de la Constitución francesa, «los tratados o acuerdos regularmente ratificados o aprobados tienen, desde su publicación, una autoridad superior a la de las leyes, bajo reserva, para cada acuerdo o tratado, de su aplicación por la otra Parte».

$58 \mathrm{Al}$ comentar el art. 55 de la Constitución francesa, se ha recordado esa interiorización de la Convención de Viena de 1969 por Carcassonne, G.: La Constitution, Paris, Éditions du Seuil, 5. ${ }^{a}$ ed., 2002, p. 250.

59 Véase art. $106 \mathrm{CE}$, así como arts. 6 y 8 LOPJ. El citado paralelismo lo ha resaltado claramente Peces-Barba Martínez, G., con Prieto Sanchís, L.: op.cit., p. 151: «La relación entre el tratado y la ley, según la interpretación referida del art. 96.1, es análoga a la que se establece entre la ley y el reglamento».

60 Así lo ha observado Torres del Moral, A.: «El Tribunal Constitucional español en negativo: lagunas y rectificaciones; cuestiones disputadas, inéditas, irresueltas, menores y de lege ferenda", en BazÁn, V. (Coord.): Derecho Procesal Constitucional Americano y Europeo, Tomo I, Buenos Aires, AbeledoPerrot, 2010, en especial, el epígrafe «Recepción del Derecho europeo por el Tribunal Constitucional: una asignatura pendiente» (pp. 718-724). 
cuidado con que se emiten las consultas legislativas» ${ }^{61}$. Y proseguía: «Al examinar los anteproyectos legislativos, el Consejo de Estado realiza además lo que se ha venido llamando "control de convencionalidad". Es enteramente aplicable aquí la conclusión a la que ha llegado la doctrina francesa respecto a su Conseil d'État: desde que es consultado de un anteproyecto de ley, el Consejo de Estado debe sistemáticamente plantearse la cuestión de saber si ese proyecto es compatible con el Derecho Comunitario y el Derecho Internacional» ${ }^{62}$.

Pero, sobre todo, al hilo del citado ejemplo, recuerda el Consejo de Estado el carácter supralegal o prevalente de los tratados internacionales, en estos términos: «La problemática de las relaciones entre la ley interna y los tratados internacionales correspondientes y la prevalencia de la fuente internacional, es objeto de examen detenido en el Dictamen 176/1997. (...) El Dictamen 4810/1997 advierte sobre la innecesidad de las cláusulas de reserva o remisión expresas a tratados por su dudosa utilidad, dada la primacía de éstos» ${ }^{63}$. Y agrega: «En esta materia el Consejo de Estado se mueve con un mayor margen creativo, que en la materia constitucional, dado lo limitado de la intervención del Tribunal Constitucional en materia de Tratados internacionales (art. $95 \mathrm{CE}$ ) y su rechazo a controlar el respeto de los compromisos internacionales y del Derecho comunitario».

Estimo que las citas anteriores quedan plenamente justificadas. Si se aplica esa lógica argumentativa al terreno de la técnica legislativa (fase de elaboración de la norma), ¿qué impide trasladarla al campo de la praxis judicial (fase de aplicación de la norma)? A mi entender, los argumentos tendentes a excluir el neto control difuso de convencionalidad de la esfera judicial ordinaria para reconducirla a la supervisión concentrada de la jurisdicción constitucional ${ }^{64}$, parecen poco realistas y, sobre todo, se alejan del principal papel y mayor virtud del primer control, a saber, la efectividad de la tutela judicial de los derechos fundamentales en plazo razonable. Efectivamente, al margen de ese obstáculo principal consistente en diferir el control a sede jurisdiccional constitucional con la consiguiente demora, se presenta irrealista esa solución por implicar incluso un cambio de mentalidad que, hoy por hoy, no se atisba todavía en la Justicia constitucional española: como se vio, ésta ha rechazado incluir los tratados como parte del bloque de constitucionalidad al tiempo que, de facto, los ha utilizado aleatoriamente como tal parámetro.

Curiosamente, ha asumido el instituto francés del bloque de constitucionalidad con esa poca fortuna y aleatoriedad y, al tiempo, se ha mostrado reacio a reconocer explícitamente que la justicia ordinaria francesa está habilitada para ejercer el control

${ }^{61}$ Memoria anual del año 2007, p. 149.

62 Memoria anual del año 1997, p. 158.

63 Ibidem, pp. 164-165.

64 Esa postura, que no comparto, de «absorción» del control de convencionalidad, por parte de la Jurisdicción Constitucional, fue anticipada en España por BAndrés SÁnCHEZ-CruZAT, J.M.: Derecho Administrativo y Tribunal Europeo de Derechos Humanos, Madrid, Civitas/Ministerio de Justicia, 1996, pp. 134-136. Y, más reciente y ampliamente, Canosa UsERA, R.: op.cit. 
de convencionalidad. Dicho sea de paso, es mi parecer que tampoco hace falta que el TC efectúe ese reconocimiento, que ya se desprende de la propia Carta Magna de 1978. Ahora bien, el aval del TC serviría ciertamente para apuntalar la convicción y la voluntad positiva de los órganos jurisdiccionales ordinarios. Por el contrario, a día de hoy, no se vislumbra ese aval, hasta tal punto que podría argüirse que la Corte Constitucional española, en materia de control de convencionalidad, ni hace ni deja hacer, como en el seno del propio Tribunal se ha criticado.

Así, gran interés despierta el voto particular concurrente de Juan Antonio Xiol Ríos (al que se adhieren Adela Asua Batarrita y Fernando Valdés Dal-Ré) formulado a la STC 270/2015, de 17 de diciembre, en donde se afirma que la cuestión del control de convencionalidad «debería ser sometida a una reconsideración más profunda por este Tribunal para evitar determinadas situaciones paradójicas que se plantean en el ordenamiento jurídico español» y con respecto a lo cual «este Tribunal, como máximo intérprete de la Constitución, deberá pronunciarse más fundadamente en algún momento». Y se recapitula así la crítica a esa elusión del control de convencionalidad: «La actual jurisprudencia parece que aboca a que sólo se posibilite el desarrollo de ese control de convencionalidad de manera concreta por parte de los órganos judiciales cuando deba aplicarse la ley que se estime contraria a un tratado internacional a partir de considerarlo una mera cuestión de selección normativa, lo que, en su caso, podría ser impugnado en amparo por la vía del artículo 24.1 de la Constitución española en caso de arbitrariedad o irrazonabilidad. No deja de resultar paradójico que en el contexto de una creciente propensión al control abstracto de normas con fundamento en razones de seguridad jurídica, el único control abstracto que quede ayuno de cualquier vía de planteamiento sea el control de convencionalidad de las normas con rango de ley que, si no puede ser ejercido por la jurisdicción ordinaria, tampoco este Tribunal está posibilitando que se ejerza a través del recurso de inconstitucionalidad o la cuestión de inconstitucionalidad por la vía de la invocación de los artículos 9.1 o 96 de la Constitución española».

En estas coordenadas, los recelos dogmáticos (y jurisdiccionales) se presentan tanto más injustificados cuanto que, en la praxis (y el cómputo no puede ser estadísticamente más sencillo, por su carácter excepcional), el ejercicio responsable del control de convencionalidad se operará en supuestos aislados en los que la norma internacional (y, sobre todo, la jurisprudencia internacional correspondiente) ofrezcan claridad y certeza en cuanto al supuesto controvertido, como ha quedado ilustrado en el terreno de los derechos sociales, con acertada fundamentación teórica ${ }^{65}$ y práctica $^{66}$.

65 Ese control de convencionalidad se desprende, entre otros, de los arts. 10.2 y 93 a 96 de la Constitución española, en conjunción con el art. 1.5 del Código civil y arts. 23.3 y 30.1 de la Ley 25/2014 de Tratados y otros Acuerdos Internacionales, como bien sostiene Jimenez García, F.: «La protección internacional de los derechos sociales y económicos. Avances recientes, técnicas de aplicación y propuestas de reforma constitucional», Revista Europea de Derechos Fundamentales, n. ${ }^{\circ}$ 25, 2015, p. 54.

66 Ilustraciones prácticas en SAlcedo Beltrán, Carmen, «La aplicabilidad directa de la Carta Social Europea por los órganos judiciales», Trabajo y Derecho, núm. 13, 2016, pp. 27-52. 
Desde esta óptica, el incorrecto ejercicio del control de convencionalidad por los órganos jurisdiccionales puede evidentemente ser sometido a escrutinio ante instancias ulteriores siguiendo el sistema de recursos ${ }^{67}$, para dotar de certeza al ordenamiento jurídico y robustecer el sistema de derechos fundamentales. Lo mismo sucede, y con mayor frecuencia (por la inflación normativa generada por el Derecho derivado y secundario), con la puesta en práctica de los principios de primacía y efecto directo del Derecho comunitario europeo, susceptible de provocar inseguridad jurídica y violación de derechos, cuyo remedio o corrección ante el TC ha venido de la mano del derecho a la tutela judicial efectiva del art. 24.1 CE (por todas, STC 64/1991, de 22 de marzo) ${ }^{68}$. Y, con claro agravio con respecto al control de convencionalidad, naturalmente no se pone en entredicho el juego de esos principios de primacía y efecto directo del Derecho de la UE que, al contrario, se han saludado con entusiasmo ${ }^{69}$.

\section{LA AFECTACIÓN FAVORABLE DE LAS NORMAS INTERNACIONALES AL BLOQUE DE VALORES, PRINCIPIOS Y DERECHOS CONSTITUCIONALES}

Por lo pronto, la incorporación de España, y de cualquier país, a la organización universal de las Naciones Unidas (ONU), o al sistema regional correspondiente (en nuestro caso, el europeo), supone la aceptación de esos valores, principios y derechos que, como consecuencia, se incorporan al orden constitucional de cada Estado miembro (en nuestro caso, en la «parte dogmática» de la Ley Suprema, esto es, básicamente el Título Preliminar y el Título I). Así, los prolegómenos transicionales de la adopción de la Carta Magna española de 1978 vinieron marcados por la aceptación en 1977 de los dos Pactos internacionales de 1966 sobre derechos civiles y políticos y derechos económicos, sociales y culturales. El dinamismo de ambos Pactos, a través de sus respectivos Comités (el de Derechos Humanos, y el de Dere-

${ }^{67}$ Un claro ejemplo lo suministra la Sentencia del TSJ de Andalucía (Sala de lo Contencioso-Administrativo) de 4 de marzo de 2008 (recurso n. ${ }^{\circ}$ 787/2007) al descartar la aplicación de la Ley Orgánica de Educación de 2006 (LOE) reconociendo el derecho a la objeción de conciencia de los padres frente a la asignatura (prevista legalmente) «Educación para la ciudadanía y los derechos humanos» con supuesto apoyo en la jurisprudencia del TEDH (se utilizaban, pero incorrectamente, las dictadas en fecha 29 de junio de 2007 - caso Folguero y otro contra Noruega-y en fecha 9 de octubre de 2007 — caso Eylem Zengin contra Turquía-. Dicha Sentencia del TSJ andaluz fue revocada en casación por la Sala de lo Contencioso-Administrativo (Sección 1. a) del TS (Sentencia de 11 de febrero de 2009, recurso de casación n. ${ }^{\circ}$ 905/2008).

${ }^{68}$ Mangas Martín, A.: «La Constitución y el Derecho comunitario», op.cit., p. 197.

69 Como ha advertido Biglino Campos, P.: «La primacía del derecho comunitario: una mirada contrapuesta. La perspectiva española», en Carmona Contreras, A.M. (Ed.): La Unión Europea en Perspectiva Constitucional, Cizur Menor, Thomson/Aranzadi, 2008, p. 41. 
chos Económicos, Sociales y Culturales) ha propiciado una paulatina profundización en nuestros valores, principios y derechos constitucionales ${ }^{70}$.

En ese mismo año 1977 ingresó España en el Consejo de Europa y, ya entrada en vigor la Constitución de 1978, se ratificaron los dos tratados más emblemáticos (equivalentes a los dos Pactos universales) de la organización paneuropea por excelencia con sede en Estrasburgo, a saber, el CEDH de 1950 en 1979 y la Carta Social Europea (CSE) de 1961 en 1980. Del CEDH y del TEDH, como máximos y más conocidos exponentes del Consejo de Europa, ya conocemos su influencia positiva en los valores, principios y derechos constitucionales, al comportar la asunción de los tres pilares que gobiernan dicha Organización, esto es, el Estado de Derecho, la democracia y los derechos humanos. Pero, nuestro Estado social y democrático de Derecho constituido en 1978 también contó con el acicate de adaptarse a los compromisos de la CSE de 1961 y, de hecho, ello determinó que se aprobara nuestro Estatuto de los Trabajadores de 1980 (Ley 8/1980, de 10 de marzo, derogada por el actual texto refundido, aprobado mediante Real Decreto Legislativo 2/2015, de 23 de octubre) unos meses antes de la aceptación de la CSE (Instrumento de ratificación de 29 de abril de 1980, publicado en el BOE n. ${ }^{\circ} 153$ de 26 de junio de 1980); por supuesto, una vez aceptada ésta, la menos conocida jurisprudencia del Comité Europeo de Derechos Sociales también ha ejercido una acción positiva para el perfeccionamiento de nuestros valores, principios y derechos constitucionales $^{71}$.

Ni que decir tiene que, posteriormente, la adhesión de España a las Comunidades Europeas de 1986 venía a consolidar esa incorporación de estándares internacionales positivos, hasta tal punto que cabría sostener que nuestra transición a la democracia quedó perfeccionada tras dicho ingreso. En todo caso, la pertenencia al Consejo de Europa se concibe como un paso previo a la adhesión a la UE, como parte de la fase práctica de adaptación al acervo comunitario europeo y asunción de las mismas exigencias axiológicas, a veces mediante reformas constitucionales en los países candi-

${ }^{70}$ Con tal espíritu, Salvioli, F.O.: «Indivisibilidad e interdependencia de los derechos humanos como criterios rectores para el trabajo de los órganos convencionales de monitoreo: la relación contemporánea entre los Pactos internacionales de derechos civiles y políticos, y de derechos económicos, sociales y culturales», en CANÇADO Trindade, A.A. y otros (Coords.): $O$ cinquentenário dos dois Pactos de direitos humanos da ONU, Vol. 1, Fortaleza, Expressão Gráfica e Editora, 2016, p. 70: el citado autor subraya «la perspectiva pro persona como herramienta útil para la interpretación y la aplicación que llevan delante los órganos cuasi judiciales y jurisdiccionales de tutela internacional en los planos universal y regional». Para el encuadre de la creciente proyección del Comité DESC, acúdase a BonET PÉrEZ, J. y Alija Fernández, R.A.: El control de los Tratados Internacionales de Derechos Humanos: realidad y límites. Una aproximación a la labor de los órganos de expertos desde la perspectiva de la efectividad de los derechos económicos, sociales y culturales, Barcelona, Atelier, 2016.

71 Véanse las fichas por países (country factsheets/fiches par pays), en donde se incluye un apartado con «ejemplos de progresos realizados en el cumplimiento de los derechos reconocidos en la Carta Social». Enlace con la ficha relativa a España: https://rm.coe.int/16806b7969 (último acceso 6 de noviembre de 2017). 
datos $^{72}$. Desde el inicio de la andadura de las Comunidades Europeas, los Tratados fundacionales de los años 1950 y sus reformas han subrayado la necesaria colaboración con el Consejo de Europa, o la remisión del Derecho de la UE a los tratados básicos de la Organización creada en 1949.

España todavía tiene importantes asignaturas pendientes de índole europea, sobre todo en lo atinente al Estado social. Sin embargo, el balance de la pertenencia, tanto a la UE como al Consejo de Europa, es indubitadamente positivo en cuanto a los valores, principios y derechos constitucionales. Los Tratados actuales de la UE acentúan la vigencia de éstos, que tienen una plasmación en el art. 2 TUE y, desde la reforma operada en Niza en 2001, cuentan con un mecanismo de sanción en el art. $7 \mathrm{TUE}^{73}$. Ambos preceptos han sido invocados para reprochar la actuación del Estado español con motivo del desafío independentista catalán, pero paradójica y curiosamente las medidas adoptadas por España como Estado miembro (incluida la activación del art. $155 \mathrm{CE}^{74}$ ) vendrían avaladas y exigidas por esas mismas disposiciones del TUE, para evitar que una parte del territorio español y de la UE sufra un ataque (perpetrado y alentado por los dirigentes regionales) contra el orden constitucional (español y europeo), la integridad territorial (española y europea) y el acervo compartido (entre otros elementos, democracia representativa frente a maniobras atentatorias de la normativa parlamentaria y de las minorías en el seno de la Asamblea regional, participación ciudadana frente a consultas populares adulteradas, o pluralismo informativo frente a sectarismo de medios de comunicación públicos autonómicos ${ }^{75}$ ).

72 López Guerra, L.: «Integración europea y Constituciones de los países candidatos», Cuadernos de Derecho Público, n. ${ }^{\circ} 13$, mayo-agosto 2001, en particular, pp. 253-254.

73 Vid. BAR CENDón, A.: «La Unión Europea como unión de valores y derechos: Teoría y realidad», Teoría y Realidad Constitucional, n. 3, 2014 (Ejemplar dedicado a «La integración política de Europa», II), p. 138: ante la inoperancia del art. 7 TUE, el citado autor postula «la necesidad de diseñar un nuevo instrumento de protección general de los valores fundamentales de la Unión que se dirija más a la prevención que a la sanción; a la supervisión y control permanente, que evite las violaciones de los valores fundamentales sin tener que llegar a la sanción. Pero, desde luego, ese nuevo mecanismo o instrumento jurídico — «mecanismo de Copenhague»— ha de ser completo y cubrir tanto la fase preventiva del proceso como la fase sancionadora y, en este último aspecto, la UE no debería ser tímida y debería prever las sanciones más graves para las violaciones más graves, incluida la expulsión de la Unión, hoy en día no prevista en los Tratados».

74 Vid. Resolución de 27 de octubre de 2017, de la Presidencia del Senado, por la que se publica el Acuerdo del Pleno del Senado, por el que se aprueban las medidas requeridas por el Gobierno, al amparo del artículo 155 de la Constitución (BOE n. ${ }^{\circ} 260$ de 27 de octubre de 2017).

75 Véase el Informe \#RespectPressCT. Reporteros sin fronteras pide respeto al libre ejercicio del periodismo en Cataluña, 13 de octubre de 2017, 24 pp.: (http://files.rsf-es.org/200005680-6ff5470eed/2017_RSF_ inf_respectpresscat_act.13.10.17.pdf, último acceso 6 de noviembre de 2017): en él se indica que «periodistas locales y corresponsales extranjeros denuncian campaña de ciberacoso en redes sociales y presiones propagandísticas de la Generalitat»; pudiendo leerse como recapitulación de las denuncias y testimonios de informadores que «las ansias del Gobierno de la región por imponer su relato a la prensa local, española e internacional han traspaso líneas rojas y las maniobras intimidatorias del Gobierno central español no ayudan», afirma Pauline Adès-Mevel, responsable del Área de UE y Balcanes de RSF. 
De igual manera, en el caso del CEDH, la jurisprudencia del TEDH ha avalado el asentamiento de los valores, principios y derechos constitucionales a través de cláusulas de salvaguardia, como el triple test previsto en el apartado 2 de algunas disposiciones convencionales para justificar las restricciones a los derechos, a saber, la previsión legal, la consecución de un fin legítimo y la necesidad para una sociedad democrática (arts. 8, 9, 10 y 11 CEDH o art. 4 del Protocolo n. ${ }^{\circ} 7$ ), todo ello combinado asimismo con el principio de proporcionalidad (art. $18 \mathrm{CEDH}$ ). No es factible ahora analizar la nutrida jurisprudencia del TEDH sobre esas cláusulas limitadoras. Bastará, si acaso, recordar que el Tribunal de Estrasburgo ha avalado la idea de democracia militante frente a partidos antisistema que postulan actitudes totalitarias ${ }^{76}$, o frente a docentes que pretenden adoctrinar en tal sentido en las aulas ${ }^{77}$ (independientemente de tener ideas «antisistema» fuera de las aulas ${ }^{78}$ ).

Esa jurisprudencia del TEDH, además de las disposiciones de salvaguardia que restringen los derechos sustanciales concretos, viene reforzada por la presencia de otras cláusulas que desempeñan la función de antídoto frente al totalitarismo (el art. 17 $\mathrm{CEDH}$-que alberga la cláusula fórmula «pas de liberté pour les ennemis de la liberté») o, asimismo, legitiman la adopción de medidas excepcionales o de derogación (art. $15 \mathrm{CEDH}$ ). Sobre este punto, al albur del debate en torno a la aplicación del art. 155 CE en el contexto del conflicto catalán, comprobamos que el manido principio de proporcionalidad no se vería resentido si se analizara el desafío independentista catalán como una situación más próxima al estado de excepción ${ }^{79}$ (previsto por el art. $116 \mathrm{CE}$ y, por tanto, de mayor contundencia que la previsión y uso comedido del art. $155 \mathrm{CE}$, dado que este último no requiere la notificación al Secretario General del Consejo de Europa contemplada en el art. $15 \mathrm{CEDH}$ ) generada por el «golpe» o «auto-golpe» de estado liderado por los dirigentes gubernamentales y la mayoría parlamentaria en Cataluña ${ }^{80}$.

${ }^{76}$ Vid. SSTEDH Herri Batasuna y Batasuna c. España, Etxeberría y otros c. España, y Herritarren Zerranda c. España, todas de fecha 30 de junio de 2009.

77 SSTEDH Kosiek c. Alemania y Glasenapp c. Alemania, ambas de 28 de agosto de 1986. De gran interés son las alternativas, frente al adoctrinamiento nacionalista en los colegios públicos catalanes, propuestas por Ruiz Robledo, A.: «Aprender de nuestros errores», 8 de octubre de 2017 (http://aruizrobledo.blogspot.com.es/2017/10/aprender-de-nuestros-errores.html).

78 STEDH Vogt c. Alemania de 26 de septiembre de 1995.

79 Un escenario posible, según De Carreras Serra, F.: «Crónica de un golpe de estado anunciado», El Cronista del Estado social y democrático de Derecho, n. ${ }^{\circ} 71-72$ (Monográfico "¿Cataluña independiente?), octubre-noviembre 2017, p. 34:

${ }^{80}$ Así lo ha tildado y criticado también recientemente el autor de Anatomía de un instante (Barcelona, Mondadori, 2009, 463 pp.) Javier CERCAS: «En Catalogne, une dangereuse fiction narcissique», Libération, 6 de noviembre de 2017 (http://www.liberation.fr/debats/2017/11/06/en-catalogne-une-dangereuse-fiction-narcissique_1608201, acceso el 7 de noviembre de 2017). 


\section{LA INFLUENCIA DE LOS CÁNONES INTERNACIONALES EN LA ORGANIZACIÓN DE LOS PODERES}

Los cánones internacionales moldean igualmente la organización de los poderes, institucional y territorial, por cuanto las instituciones no dejan de ser medios o instrumentos cuya misión consiste en defender los derechos y libertades. Así, ya mencionamos en el apartado 1 (supra) que en el Título II de nuestra Carta Magna eleva al Rey al rango de más alta autoridad representativa «en las relaciones internacionales» (art. 56.1 CE), asignándole también funciones en materia de guerra y paz, o de acreditación activa y pasiva de dignatarios de otros países (art. $63 \mathrm{CE}$ ). Pues bien, el caso es que, incluso la regulación constitucional de la Corona, no ha quedado exenta de los compromisos internacionales, por ejemplo, en materia de responsabilidad bajo el ángulo de la Ley Orgánica 6/2000, de 4 de octubre, por la que se autoriza la ratificación del Estatuto de la Corte Penal Internacional ${ }^{81}$.

Comentamos asimismo en ese apartado 1 que el Título IV de la Norma Fundamental establece entre las funciones del Gobierno (art. 97 CE) la de dirección de la política exterior, debiendo resaltarse ahora la de dirección de la Administración civil y militar y la defensa del Estado, funciones todas ellas que tienen una indudable proyección internacional. Dejando de lado estas concretas funciones relativas a la organización administrativa española en el exterior o a la estrategia defensiva, es sabido que una de las vertientes más ostensibles de la dirección política gubernamental se plasma en los proyectos de ley (muchos de ellos, con componente internacional) o de suscripción de tratados internacionales que el candidato a Presidente del Gobierno suele anunciar en su discurso de investidura como elemento tangible de sus compromisos electorales y su programa de gobierno. Por la misma razón (en consonancia con nuestro sistema parlamentario de gobierno), la potestad legislativa de las Cortes Generales (Título III y, en conexión, Título V) presenta una paralela vertiente internacional y, más aún, europea en un alto porcentaje $e^{82}$.

Si efectuamos un sintético repaso a la influencia, directa o indirecta, de la jurisprudencia del TEDH en los poderes del Estado, comprobamos que se ha ensanchado la proyección (tal vez excesiva) de la libertad de expresión política frente a la dignidad del Jefe del Estado ${ }^{83}$ o la reputación del Gobierno ${ }^{84}$ frente a declaraciones consideradas injuriosas en el ámbito interno; se ha reducido la prerrogativa de la inmunidad par-

81 Sobre el particular, se ha considerado en la doctrina que se ha producido una «mutación constitucional»: así, Tenorio SÁnChez, P.J.: «Estatuto de la Corte Penal Internacional y Constitución», Revista de Derecho Político, n. ${ }^{\circ}$ 51, 2001, p. 103. Vid. asimismo el Dictamen de la Comisión permanente del Consejo de Estado español, de 22 de julio de 1999 (N. ${ }^{\circ}: 1.374 / 99 / \mathrm{MM}$ ).

82 Vid. Jimena Quesada, L.: «El impacto del Derecho europeo en la legislación española. Breve balance de veinte años de integración europea», en Bou Franch, V., y Cervera Vallterra, M. (Coords.): El Derecho de la Unión Europea. 20 años después de la adhesión de España, Valencia, Tirant lo Blanch, 2007, pp. 417-459.

${ }^{83}$ STEDH Otegi c. España de 15 de marzo de 2011.

${ }^{84}$ STEDH Castells c. España de 23 de abril de 1992. 
lamentaria cuando ella puede devenir un verdadero privilegio nocivo para la separación de poderes y concretamente para la tutela judicial efectiva ${ }^{85}$, o se ha sancionado la prolongada omisión del Legislador al corregir una insuficiencia normativa atentatoria contra los derechos fundamentales ${ }^{86}$; se ha corregido el funcionamiento orgánico del poder judicial en el orden militar para hacerlo respetuoso con los derechos de defensa ${ }^{87}$; o se ha incluido, entre los poderes estatales sometidos a control convencional, a la propia Jurisdicción Constitucional ${ }^{88}$.

Para completar el presente apartado cabe agregar que, en lo concerniente a la organización territorial del Estado, nuestra pertenencia a la UE ha tenido una influencia nada despreciable. En particular, aunque la jurisprudencia del TJUE haya consagrado el principio de autonomía institucional y procedimental establecido en el sistema constitucional de cada Estado miembro ${ }^{89}$ y para el TC del art. 149.1.3. ${ }^{a}$ CE no pueda derivarse una espuria reordenación del propio orden de distribución de competencias entre el Estado y las Comunidades Autónomas ${ }^{90}$, lo bien cierto es que ello no se ha manifestado necesariamente en una potenciación de la autonomía regional, ni siquiera en la ejecución (fase descendente) de las obligaciones comunitarias pues: de un lado, la interpretación no expansiva del art. 149.1.3. ${ }^{a}$ CE no ha evitado el recurso a otros títulos competenciales centralizadores como la igualdad básica estatal del art. 149.1.1. ${ }^{a}$ CE o la ordenación general de la economía del art. 149.1.13. ${ }^{a} \mathrm{CE}$, que se han desenvuelto a modo de competencias transversales u horizontales determinantes de prevalencia estatal ${ }^{91} ; \mathrm{y}$, de otro lado, la inactividad ejecutoria de las autoridades autonómicas habilitaría para la injerencia estatal en virtud del juego conjunto de los arts. 93 CE y 149.1.3. ${ }^{a} \mathrm{CE}^{92}$.

Este último enfoque centralizador genera cierta perplejidad, puesto que no tiene su correlato en un aval de la operación inversa, es decir, de dar por buena la injerencia autonómica (basada en títulos competenciales no prevalentes) ante una inactividad estatal que no sea coherente con la lealtad doméstica en la incorporación de estándares comunitarios positivos para el disfrute de los derechos y libertades: así lo ilustra,

85 STEDH Cordova (I) c. Italia de 30 de enero de 2003.

86 STEDH Prado Bugallo c. España de 18 de febrero de 2003 (escuchas telefónicas en el marco de una investigación por tráfico de estupefacientes, con violación del art. 8 CEDH). La insuficiencia y falta de previsibilidad de la legislación española (Ley de enjuiciamiento criminal) en la materia ya había sido objeto de reproche en la STEDH Valenzuela Contreras c. España de 30 de julio de 1998).

${ }^{87}$ Vid. RAmírez Sineiro, J.M.: «La estructura orgánica de la Jurisdicción Militar: consideraciones acerca de su constitucionalidad con arreglo a la doctrina del Tribunal Europeo de Derechos Humanos», en AA.VV.: La Jurisdicción Militar, Madrid, Consejo General del Poder Judicial, 1992.

${ }_{88}$ Por todas, STEDH Ruiz Mateos c. España de 23 de junio de 1993.

89 Ello se recuerda en la STC 80/1993, de 8 de marzo, FJ 3.

90 Entre otras, SSTC 153/1989, de 5 de octubre, o 115/1991, de 23 de mayo.

91 De la Quadra-Salcedo Janini, T.: «Delimitación de competencias y principio de prevalencia», en P. PÉrez Tremps (Coord.), La reforma del Tribunal Constitucional, Valencia, Tirant lo Blanch, 2007 , p. 1025.

92 Por ejemplo, SSTC 195/1998, de 1 de octubre, o 97/2002, de 25 de abril. 
lamentablemente, la STC 62/2016, de 17 de marzo, que no se mostró sensible al parámetro finalista favorable impuesto por la normativa de la UE en materia de pobreza energética ${ }^{93}$, bajo el pretexto orgánico de la distribución competencial ${ }^{94}$. En dirección opuesta cabe recordar la postura más autonomista de nuestra jurisprudencia constitucional avalando las conocidas como «oficinas de enlace» regionales ante las instituciones comunitarias cuando esa proyección exterior «no implique el ejercicio de un ius contrabendi, no originen obligaciones inmediatas y actuales frente a poderes públicos extranjeros, no incidan en la política exterior del Estado y no generen responsabilidad de éste frente a Estados extranjeros u organizaciones inter o supranacionales» ${ }^{95}$; una limitación que, en cambio, no ha podido evitar el abuso por parte de los dirigentes catalanes impulsores del «procés» secesionista ${ }^{96}$.

\section{EL PAPEL POSITIVO DE LOS INSTRUMENTOS INTERNACIONALES EN LA DEFENSA DEL ORDEN CONSTITUCIONAL}

\subsection{La internacionalización de la función constituyente y la ponderación de la reforma constitucional}

Al hilo del citado proceso secesionista en Cataluña, no me parece oportuno en esta sede pronunciarme sobre las argucias mediáticas y procesales utilizadas por sus impulsores (de la sociedad civil o de la política — con la sonora huida a Bruselas del cesado Presidente de la Generalitat Carles Puigdemont junto a otros ex Consejeros para eludir la acción de la Justicia española) para convertir el desafío independentista en un conflicto internacionalizado. Sí es pertinente, empero, reflexionar sobre algunas

93 Particularmente, la Directiva 2009/72/CE del Parlamento Europeo y del Consejo, de 13 de julio de 2009, sobre normas comunes para el mercado interior de la electricidad, y la Directiva 2009/73 del Parlamento Europeo y del Consejo, de 13 de julio de 2009, sobre normas comunes para el mercado interior del gas natural, que son las que regulan la obligación nacional de establecer una normativa que garantice una protección adecuada de los clientes vulnerables en situaciones de pobreza energética.

94 Véase la crítica discrepante formulada en el voto particular conjunto suscrito por Adela Asua Batarrita y Fernando Valdés Dal-Ré y en el voto redactado por Juan Antonio Xiol Ríos, en los cuales se reprocha la parcial transposición por el Estado de la normativa de la UE o la existencia de una competencia compartida que legitimaría la normativa autonómica impugnada (Decreto-ley de Cataluña 6/2013, de 23 de diciembre, por el que se modifica la Ley 22/2010, de 20 de julio, del código de consumo de Cataluña). Para una perspectiva comparada, MASALA, P.: «Il coordinamento delle politiche di contrasto alla povertà e all'esclusione sociale nell'ambito dell'Unione europea e i suoi limiti di eficacia alla luce del caso italiano», en E. Rossi y V. CASAmassima (Coords.), La politica sociale europea tra armonizzazione normativa e nuova governance, Pisa, Pisa University Press, 2013, pp. 197-254.

95 STC 165/1994, de 26 de mayo, FJ 6.

96 Por ello, una de las medidas acometidas bajo el ángulo del art. 155 ha consistido precisamente en proceder al cierre de esas «embajadas» catalanas: vid. Real Decreto 945/2017, de 27 de octubre (BOE n. ${ }^{\circ} 261$, de 28 de octubre). 
aristas relacionadas con la punta de lanza utilizada por dichos impulsores para recrudecer su hoja de ruta separatista, a saber, el trasfondo de la STC 31/2010, de 28 de junio, sobre el Estatuto catalán (sobre cuyo impacto, en términos de redacción, de extensión y de contenido, no persigo reflexionar ahora ${ }^{97}$ ), que en verdad ha hecho recaer un peso demagógicamente exagerado e injustificado sobre la Jurisdicción Constitucional so pretexto de que el nuevo texto estatutario catalán habría sido privado de esencia pese a haber sido sometido a referéndum en Cataluña.

Lo cierto es que Álvarez Conde y Tur Ausina, sin dejar de hacerse eco de los comentarios positivos y negativos dirigidos a la STC 31/2010 y aportar sus propios planteamientos científicos con objeto de rellenar los espacios de inseguridad jurídica creados por el marcado carácter interpretativo de la Sentencia ${ }^{98}$, enfocan sagazmente la problemática esgrimiendo que «la cuestión más importante es determinar los efectos jurídicos de la sentencia, su ejecución por parte de los diferentes operadores jurídicos, y el futuro de nuestro modelo autonómico», para no enrocarse en el pasa$\mathrm{do}^{99}$. De lo contario, la no asunción de responsabilidad por los actores políticos con capacidad decisoria provocará nuevamente que el TC se arrogue eventualmente la posición del poder constituyente.

Estos términos del debate han sido objeto de reflexión escrutando las posibilidades, inviables, de someter a revisión internacional la STC 21/2010, concretamente ante el TEDH ${ }^{100}$. Particularmente, se ha pretendido presentar la controversia como una especie de choque de legitimidades (entre el TC y el cuerpo electoral catalán) que resulta ficticio, falaz y más complejo, no siendo ocioso cuestionarse el modo en que determinada clase política provocó el sometimiento de la nueva norma estatutaria al TC

${ }^{97}$ Acúdase a tal efecto, con carácter exhaustivo, al excelente análisis efectuado por ÁLVAREZ Conde, E. y Tur Ausina, R.: Las consecuencias jurídicas de la Sentencia 31/2010 de 28 de junio del Tribunal Constitucional sobre el Estatuto de Cataluña. La Sentencia de la Perfecta Libertad, Cizur Menor, Aranzadi, 2010.

98 Álvarez Conde, E. y Tur Ausina, R.: op.cit., pp. 9-18.

99 Ibidem, p. 15-16: «No se trata de volver al pasado, hablando del proceso de elaboración del Estatuto y su aprobación por referéndum, de la tardanza del Tribunal en resolver, de las presiones políticas sufridas por el mismo, de las responsabilidades (bien distintas, por cierto) de unos partidos y de otros, de las reacciones viscerales que se han producido, de las filtraciones de la propia sentencia, y un largo etcétera. Creemos que hay que elevarse, trascender del caso concreto del Estatuto de Cataluña, lo cual no es lo mismo que negar la importancia jurídica y política del mismo. De lo que se trata es de efectuar reflexiones serias y sosegadas en el sentido de si es necesario o no —en nuestra opinión creemos que sí-, realizar determinadas operaciones normativas (incluida, por supuesto, la reforma constitucional que, hoy por hoy, se nos antoja como la única medida seria y eficaz) con la finalidad de consolidar un modelo de descentralización política que no sea cuestionado o puesto en tela de juicio cada diez o veinte años (...). Y todo ello superando los intereses electorales de los partidos políticos y planteando la cuestión, con luz y taquígrafos, a la ciudadanía, en quien reside, a la postre, el poder constituyente, el cual no puede ser usurpado por ningún poder constituido, estatal o autonómico».

100 Vid. Bayona Rocamora, A.: «La impugnación de la Sentencia: posibilidades de acceso al TEDH» (pp. 475-478); así como Queralt JimÉneZ, A.: ¿La Sentencia sobre el Estatuto catalán ante el TEDH? (pp. 479-484), ambos en Revista Catalana de Dret Públic, número monográfico Especial sentència sobre l'Estatut, 2010. 
tras haberlo «vendido» demagógicamente a la ciudadanía como baluarte indiscutible de la democracia ${ }^{101}$. Pero sabemos que la democracia es regla de la mayoría con respeto de la minoría, no faltando experiencias de normas (incluso constitucionales) avaladas por referendos y, pese a todo, desautorizadas tras haber recabado la adhesión mayoritaria (con mayor o menor manipulación, según el planteamiento o la formulación de las preguntas sometidas a consulta $)^{102}$ para la asunción de medidas contrarias a la dignidad y a los derechos humanos.

Así, en Europa, ya en la STEDH Tyrer c. Reino Unido, de 25 de abril de 1978, los castigos corporales institucionalizados en la Isla de Man fueron declarados contrarios al derecho a no ser sometido a tratos degradantes (art. $3 \mathrm{CEDH}$ ), no siendo de recibo para la Corte de Estrasburgo el argumento del Gobierno denunciado basado en que una amplia mayoría acreditada (superior a dos tercios) de los electores de la Isla eran partidarios de esa violencia física como medida de disciplina escolar. Un supuesto válido asimismo para la reflexión tuvo lugar en el marco del sistema interamericano, en donde la Corte de San José de Costa Rica alertó a través de la Opinión Consultiva OC-14 de 9 de diciembre de 1994 sobre la contrariedad del entonces nuevo art. 140 de la Constitución política del Perú de 31 de diciembre de 1993 (ampliaba los supuestos delictivos punibles con la pena capital) al principio de progresividad establecido en el artículo 4.2 de la Convención Americana de Derechos Humanos, por más que ese nuevo supuesto hubiese sido ratificado por mayoría mediante referéndum.

Con estos parámetros, estimo que el debate de mayor enjundia para la reintroducción del recurso previo mediante la Ley Orgánica 12/2015 no radicaba tanto en el hecho de que pueda mediar un referéndum (aunque comprenda las razones para que tal circunstancia haya merecido una atención o referencia especiales en el Preámbulo de dicha Ley) sino en las disfunciones provocadas por la anulación de disposiciones tras varios años de controvertida o incierta vigencia ${ }^{103}$. Pues, como se ha visto, los

101 Tajadura Tejada, J. (Coord.): Diez propuestas para mejorar la calidad de la democracia en España (Informe Funciva), Madrid, Biblioteca Nueva, 2014, p. 111.

102 Léase, a fortiori, la crítica de CASTEllà ANDreu, J.M.: «Secesión y referéndum sobre el “derecho a decidir" en Cataluña. Una aproximación desde el Derecho Constitucional», en OLIVER Araujo, J. (Dir.): El futuro territorial del Estado español. ¿Centralización, autonomía, federalismo, confederación o secesión?, Valencia, Tirant lo Blanch, 2014, pp. 451-490. Esta crítica no es incompatible con otra crítica paralela a la visión restrictiva del referéndum consultivo autonómico en la STC 31/2010, pues dentro del modelo constitucional del referéndum «no cabría objetar la presencia de esta figura en las CCAA», como ha señalado el propio CASTELlà ANDREU, J.M.: «Las consultas populares en la Sentencia 31/2010 sobre el Estatuto de Autonomía de Cataluña», en ÁlvarEz CondE, E., y RosADo Villverde, C. (Dirs.): Estudios sobre la Sentencia 31/2010, de 28 de junio, del Tribunal Constitucional sobre el Estatuto de Autonomía de Cataluña, Madrid, Instituto de Derecho Público-Universidad Rey Juan Carlos, 2011, p. 220.

103 Alegre Martínez, M.A.: «El resurgimiento del debate sobre el control previo de constitucionalidad en España: experiencia y perspectivas», Revista Iberoamericana de Derecho Procesal Constitucional, n. ${ }^{\circ}$ 8, 2007, pp. 3-29, disponible asimismo en http://bibliohistorico.juridicas.unam.mx/libros/6/2553/6 pdf (última visita el 3 de noviembre de 2016), p. 17. 
estándares internacionales sobre derechos humanos pueden llegar a jugar como límites a una reforma constitucional ${ }^{104}$, incluso confirmada mediante referéndum si la consulta no presenta suficiente adecuación democrática ${ }^{105}$.

En definitiva, se ha insistido sensatamente en que la experiencia de la STC 31/2010 debería ser aprovechada para una serena y consensuada reforma constitucional, pues «el Derecho Constitucional, como Derecho de la libertad y la igualdad, y el propio principio democrático, como elemento nuclear del mismo, exigen acomodar los preceptos constitucionales, a través de su reforma expresa, a los nuevos tiempos que estamos viviendo. Lo que no puede aceptarse es la proclamación del fracaso absoluto de la vía autonomista y, por ende, de nuestro sistema constitucional, afirmando, desde opciones políticas interesadas, que sólo es posible una vía rupturista, de carácter soberanista o jacobina, que ponga en tela de juicio las virtualidades de nuestro sistema autonómico» ${ }^{106}$. A condición, por lo tanto, de no situarse en la órbita del fraude constitucional ${ }^{107}$.

\subsection{Los cánones internacionales y la jurisdicción constitucional}

Como se analizó más arriba, incluso la jurisdicción constitucional ha venido moldeada en su funcionamiento por los cánones internacionales, señaladamente en el ámbito de los derechos humanos y, en particular, en el diálogo con el TJUE a través de la cuestión prejudicial (apartado 2, supra) o en el curso del agotamiento de los recursos internos ante el TEDH (apartado 7, supra). Procede, ahora, completar esos aspectos por referencia a otros dos elementos de interés en la relación del TC con el TEDH: uno, la crítica europea hacia la deficitaria motivación de las resoluciones de inadmisión de recursos por el TC; el otro, el prospectivo diálogo entre el TC y el TEDH.

104 Con tal orientación, Wong Meraz, V.A.: «Los derechos fundamentales y humanos como límite a la reforma constitucional desde la perspectiva democrática y humanista», en CERVANTES BRAvo, I., y Wong Meraz, V.A. (Coords.): Temas de control de constitucionalidad y convencionalidad en México, México, Porrúa, 2013.

105 Flauss, J.F.: «L'internationalisation de l'exercice de la fonction constituante: une nouvelle forme de constitutionnalisme?», en el colectivo Essays in honour of Georgios I. Kassimatis, Bruxelles, Ant. N. Sakkoulas/Berliner Wissenschafts/Bruylant, 2004, pp. 401-433.

106 Álvarez Conde, E. y Tur Ausina, R.: Las consecuencias jurídicas de la Sentencia 31/2010 de 28 de junio del Tribunal Constitucional sobre el Estatuto de Cataluña. La Sentencia de la Perfecta Libertad, op.cit., p. 260.

107 Como perspicazmente ha observado Ruipérez Alamillo, J.: «La nueva reivindicación de la secesión de Cataluña en el contexto normativo de la Constitución Española de 1978 y el Tratado de Lisboa», Teoría y Realidad Constitucional, n. ${ }^{\circ} 31$, 2013, p. 132: en la medida en que el Constituyente de 1977-1978 excluyó «el reconocimiento constitucional del ius secessionis, su inclusión a través de la utilización del amending process no podría ser considerado como la realización de una simple reforma constitucional, a través de la cual se procede a la substitución de unas soluciones jurídicas por otras, sino, muy al contrario, como la materialización de un auténtico fraude constitucional». 
En cuanto a lo primero, el casi infranqueable criterio de la «especial trascendencia constitucional» ha ido ciertamente perfilándose en la jurisprudencia constitucional (sobre todo, STC $155 / 2009$, de 25 de junio) ${ }^{108}$, en buena medida tras alguna llamada de atención del $\mathrm{TEDH}^{109}$, como ha sido reconocido en el seno del propio $\mathrm{TC}^{110}$. Sea como fuere, esos perfiles más específicos, que han conducido a una cierta o mayor motivación por parte del TC en sus providencias de inadmisión con apoyo en dicho criterio previsto en el apartado b) del art. 50.1 LOTC, no han dejado de configurar semejante criterio como un obstáculo casi insalvable ${ }^{111}$.

Conscientes de ello y de esa aparente evolución jurisprudencial, los representantes procesales de los recurrentes en amparo se han esmerado crecientemente en argumentar esa especial trascendencia constitucional, topándose entonces contra otra barrera, ahora sí, prácticamente insuperable, a saber, el criterio previsto en el apartado a) del propio art. 50.1 LOTC («Que la demanda cumpla con lo dispuesto en los artículos 41 a 46 y 49» de la propia LOTC). Con soporte en dicho apartado, el TC viene a utilizar en sus providencias una lapidaria fórmula a tenor de la cual «La Sección ha examinado el recurso presentado y ha acordado no admitirlo a trámite, con arreglo a lo previsto en el art. 50.1.a) LOTC, dada la manifiesta inexistencia de violación de un derecho fundamental tutelable en amparo».

Presuponiendo la buena fe de todas las partes, no me veo legitimado para descartar la excepcional o eventual existencia de abuso por parte de los recurrentes (inducidos o no por eventual temeridad o falta de deontología profesional de los representantes procesales). Correlativamente, tengo la fuerte convicción de que esa fórmula utilizada por el TC presenta serios ingredientes de arbitrariedad, por tra-

108 Un exhaustivo análisis de la «especial trascendencia constitucional» (pp. 95 y ss.) y de los demás aspectos procedimentales del amparo constitucional, en la obra de Tenorio SÁNCHEZ, P.: El recurso de amparo ante el Tribunal Constitucional. Perspectivas de reforma, Madrid, Fundación Wolters Kluwer, 2014.

109 Véase la STEDH Arribas Antón c. España de 20 de enero de 2015 y jurisprudencia allí citada.

$110 \mathrm{Al}$ analizar el requisito de la «especial trascendencia constitucional» del art. 50.1.b) LOTC, el TC suele introducir en efecto una mínima argumentación o motivación, a la luz precisamente de los criterios sentados por el TEDH en el citado caso Arribas Antón. Así se destaca en la ponencia del Presidente del TC español, Francisco Pérez de los Cobos, titulada «El diálogo entre el Tribunal Europeo de Derechos Humanos y el Tribunal Constitucional Español: una relación fructífera», pronunciada en el marco de la Conferencia Internacional «Los retos y perspectivas de la justicia constitucional contemporánea», que se celebró el 17 de mayo de 2016 en San Petersburgo (Rusia) con motivo de la conmemoración del XXV aniversario de la Corte Constitucional rusa; de las siete páginas de la ponencia, dos de ellas (pp. 3 y 4) abordan ese caso Arribas Antón y su toma en consideración por el TC (disponible en http://www.tribunalconstitucional.es/es/actividades/Documents/2016_05_17/Ponencia $\% 20$ del $\% 20$ Presidente $\% 20$ del $\% 20$ Tribunal\%20Constitucional.pdf, última visita el 10 de septiembre de 2017).

111 Por ello, cabe cuestionar que ese duro trámite de admisión de la demanda de amparo haya quedado vertebrado conforme al tenor positivo y objetivo pretendidamente articulado a la vista de los modelos del Tribunal Supremo Federal de los Estados Unidos y del Tribunal Constitucional Federal Alemán. Cf. Hernández Ramos, M.: El nuevo trámite de admisión del recurso de amparo constitucional, Madrid, Editorial Reus, 2009. 
tarse de una cláusula inmotivada o un cheque en blanco (alejados asimismo de la propia jurisprudencia del TEDH mencionada en el referido caso Arribas Antón) que deja inermes a los justiciables, a quienes sólo queda confiar en una igualmente improbable tutela efectiva ante el Tribunal de Estrasburgo, acostumbrado asimismo a la utilización de estereotipadas fórmulas de inadmisión en masa, como que la demanda estaría «manifiestamente mal fundada» o adolecería de «falta de apariencia de violación de derechos».

Por lo demás, el segundo elemento de interés avanzado tiene que ver con la consulta prevista en el Protocolo n. ${ }^{\circ} 16$ al CEDH (de 2 de octubre de 2013 ) $^{112}$ ante el Tribunal de Estrasburgo. Cuando se produzca la vigencia del citado instrumento (conocido como «Protocolo del diálogo») y España lo ratifique, la dinámica habrá de ser análoga a la de la sustanciación del recurso de amparo en cuyo marco se genere una cuestión prejudicial (con suspensión del plazo para dictar sentencia), pese a que la sentencia prejudicial del TJUE sea vinculante y la opinión consultiva del TEDH no lo sea. Efectivamente, la eventual consulta al TEDH en virtud del Protocolo n. ${ }^{\circ} 16$ en principio sólo se producirá en el contexto de un recurso de amparo (en esta cognición concreta diverge el Protocolo n. ${ }^{\circ} 16$ de la competencia consultiva abstracta — activada sólo a solicitud del Comité de Ministros del Consejo de Europa- prevista en los arts. 47 a $49 \mathrm{CEDH}$ ) y, aunque la opinión del TEDH no revista obligatoriedad, debería asumirse como tal pues, de lo contrario, tras el agotamiento de la vía judicial previa ante el propio TC, éste se vería desautorizado en Estrasburgo tras la correspondiente demanda individual ${ }^{113}$.

\subsection{La inadmisible banalización del Derecho internacional y del Derecho constitucional}

Pese a la manida crisis del Estado nacional, manifestada en la convicción de su pequeñez para abordar ciertos problemas y de su desmesurado tamaño para resolver otros, «en medio de esa bipolar tensión, la inercia histórica y el sentimiento de resistencia frente al exterior y de unidad frente a movimientos interiores juegan en favor de la persistencia de los Estados nacionales». En tales condiciones, finalizado el sistema de bloques en las relaciones internaciones, se ha alertado sobre los «nuevos brotes de nacionalismo independentista» que se están sucediendo en Europa como «una de las principales fuentes de conflicto en nuestro Continente» ${ }^{114}$.

112 Dicho Protocolo entrará en vigor cuando reúna diez ratificaciones. A fecha 7 de noviembre de 2017 contaba con ocho ratificaciones (Albania, Armenia, Estonia, Finlandia, Georgia, Lituania, San Marino y Eslovenia); España ni siquiera lo ha firmado hasta la fecha.

113 Así lo advirtió el Ex Presidente del TEDH: Discours du Président Dean Spielmann; Séminaire Tribunal constitutionnel, Madrid, 22 mai 2015; accesible en: http:/www.echr.coe.int/Documents/ Speech_20150522_OV_Spielmann_Tribunal_constitutionnel_Madrid_FRA.pdf (visitado el 29 de agosto de 2016), p. 7.

114 Torres del Moral, A.: Estado de Derecho y democracia de partidos, op.cit., p. 112.

(C) UNED. Revista de Derecho Politico

N. ${ }^{\circ} 101$, enero-abril 2018, págs 819-866 
Ahora bien, si algunas secesiones han encontrado un rápido reconocimiento en el continente europeo por parte de los demás Estados y de la propia ONU, explicables por la artificialidad de su conglomerado previo para atender necesidades de reconstrucción posbélica y como respuesta a la política internacional de bloques (la explosión de la antigua Unión Soviética o de la ex Yugoslavia, o la escisión de Checoslovaquia), cuando la unión o integración de unidades en un Estado (como las denominadas «nacionalidades y regiones» en el art. 2 CE) se realizó por vías políticas, pactadas y pacíficas y/o se ha asentado a través de varios siglos, «resulta menos atendible en Derecho internacional la reivindicación separatistas de alguna de ellas después de cuatrocientos o quinientos años» ${ }^{115}$.

Verdaderamente, si el principio de las nacionalidades formulado a mediados del siglo XIX por Mancini conoció una plausible reformulación en el seno de la ONU como derecho de autodeterminación tras la segunda guerra mundial en los Pactos internacionales de 1966 (art. 1 común a ambos), resulta ahora francamente pretencioso y osado revestirlo de derecho a decidir en escenarios como el «conflicto catalán» ${ }^{116}$. Cabalmente, buscar paralelismos del desafío independentista catalán en España con el caso quebequés en Canadá o el escocés en Reino Unido, o incluso la «vía eslovena» en la antigua Yugoslavia, conlleva una lectura histórica plagada de ligereza ${ }^{117}$; mientras que compararlo con el supuesto de Kosovo, ello comporta sencillamente un ejercicio agraviante para las víctimas del conflicto bélico de 1999 y la consecuente crisis humanitaria, además de una lectura sui generis acerca del alcance de la Opinión Consultiva emitida por la Corte Internacional de Justicia el 22 de julio de $2010^{118}$.

En particular, efectuar un parangón de los citados casos con el conflicto en Cataluña, especialmente a la luz de la incontrolada participación popular en el pretendido referéndum del 1 de octubre de 2017 o de la extraña votación en la voluntariosa declaración de independencia del Parlamento catalán el 27 de octubre de $2017^{119}$,

115 Ibidem, p. 114.

116 Cf. Barceló i Serramalera, M., y otros: El derecho a decidir. Teoría y práctica de un nuevo derecho, Barcelona, Atelier, 2015.

117 Vid. Hayden, R.M.: Blueprints for a House Divided. The Constitutional Logic of the Yugoslav Conflicts, Ann Arbor, University of Michigan Press, 4. ${ }^{a}$ ed., 2003, o, más recientemente, CaPlan, R.: Europe And The Recognition Of New States In Yugoslavia, London, Cambridge University Press, 2015.

118 International Court of Justice, Advisory Opinion of 22 July 2010 (Accordance with International Law of the Unilateral Declaration of Independence in respect of Kosovo): https://www.webcitation.org/5rRB9e3bz?url=http://www.icj-cij.org/docket/files/141/15987.pdf (última visita el 2 de septiembre de 2017).

119 Tomando en consideración las cifras reales de participación en Cataluña en las distintas convocatorias electorales celebradas dentro del orden constitucional y con las debidas garantías, se constata que la «cuestión catalana» está sobredimensionada políticamente en términos de porcentaje de apoyo al separatismo (no ha alcanzado nunca ni siquiera la mitad del voto expresado), como ha observado BAR CEndón, A.: «El proceso independentista de Cataluña y la doctrina jurisprudencial: una visión sistemática», Teoría y Realidad Constitucional, n. ${ }^{\circ}$ 37, 2016 (Ejemplar dedicado a «La cuestión catalana»), p. 214-215. 
resulta ser una inadmisible banalización del Derecho internacional y del Derecho constitucional meridianamente reflejada en la aprobación por el Parlamento autonómico de sendas Leyes de desconexión (Ley 19/2017, de 6 de septiembre, del referéndum de autodeterminación y Ley 20/2017, de 8 de septiembre, de transitoriedad jurídica y fundacional de la República). Tanto las sesgadas invocaciones efectuadas por parte del Parlamento regional al derecho a decidir en nombre del Derecho internacional, como la flagrante vulneración del bloque constitucional español (la Constitución de 1978 apoyada a la sazón por el pueblo en Cataluña o las resoluciones del TC español ${ }^{120}$, así como el propio Estatuto de Autonomía y el Reglamento parlamentario) han sido inauditos y, por ello mismo, no merecerían mayor comentario ${ }^{121}$. La reflexión no es nueva; ya observó Leibholz en los años sesenta del siglo pasado «aludiendo al Derecho constitucional e internacional», que «en las relaciones tanto internas como internacionales existen una serie de vínculos de los cuales el "Soberano" no se puede eludir sin limitar inequívocamente su soberanía»; y agregaba: «en una democracia el soberano, es decir el pueblo, está a través del Derecho supedito a éste y, por lo tanto, limitado en su libertad de decisión» ${ }^{122}$.

Naturalmente, no configuran estas páginas el espacio idóneo para terciar en un debate (exponencialmente saturado online) sobre la batalla manipulativa en medios de comunicación (habiéndose verificado falaces, surrealistas y esperpénticos episodios de internacionalización del desafío independentista catalán) o sobre episodios vergonzantes de perjurio en sede parlamentaria utilizando la portada de 2012 de una revista internacional como referida al día después del referéndum inconstitucional del 1 de octubre de 2017 (¿hasta qué punto debe quedar impune, social o jurídicamente, la falta de deontología informativa o la trivialización de la inviolabilidad parlamentaria?). Desde esta perspectiva, los argumentos breve y claramente expuestos, en sendos manifiestos o declaraciones, por centenares de integrantes de la Asociación de Constitucionalistas de España ${ }^{123}$ y de la Asociación Española de Profesores de Derecho Internacional y Relaciones Internacionales con respecto a la convocatoria inconstitucional del

${ }^{120}$ Lógicamente, el TC (Sentencias de 31 de octubre de 2017) ha declarado nulas e inconstitucionales igualmente las derivaciones aplicativas de la Ley catalana 19/2017, es decir, la Resolución 807/XI del Parlamento de Cataluña por la que se designan los miembros de la sindicatura electoral de Cataluña, el Decreto 140/2017, de 7 de septiembre, de la Generalitat de Cataluña, de normas complementarias para la celebración del referéndum de autodeterminación, y el Decreto 139/2017, de 6 de septiembre, de convocatoria del Referéndum de Autodeterminación de Cataluña.

121 Con fino análisis del ius secesssionis — que comparto- lo ha expresado, refiriéndose a «la absoluta complementariedad del Derecho Constitucional y del Derecho Internacional», Ruipérez AlamiLLO, J.: «La nueva reivindicación de la secesión de Cataluña en el contexto normativo de la Constitución Española de 1978 y el Tratado de Lisboa», ya cit., especialmente pp. 112-118.

122 Leibholz, G.: Conceptos fundamentales de la Política y de Teoría de la Constitución, Madrid, Instituto de Estudios Políticos, 1964, pp. 262.263.

${ }^{123}$ Manifiesto de profesores españoles de Derecho Constitucional a favor del cumplimiento de la Constitución (https://docs.google.com/document/d/11Brt6BtrVBCwet6biDO5Mr-3WNEp0Or0bCdUjsIA-VY/edit). 
referido referéndum de autodeterminación del 1 de octubre de 2017, eximen de ulterior argumentación ${ }^{124}$.

Sin embargo, la reseñada banalización del Derecho internacional y del Derecho constitucional hacen insoslayable una crítica en clave académica. ¿Hemos acaso reparado en la responsabilidad de los universitarios que han estado alimentando el llamado «procés» en Cataluña al servicio de la casta política beneficiaria directa de semejante despropósito? Evidentemente, el secesionismo y los anhelos independentistas tienen su cabida en el plano de las ideas políticas y académicas. En cambio, la puesta en práctica de tales ideas no debe caer en prácticas anticonstitucionales y aun delictivas en el ejercicio de los cargos públicos (seguramente resultará complejo explicarse a los responsables políticos del «procés» en cuanto a la mentira colectiva que han infundido a una población esperanzada con una meta hoy por hoy irrealizable, o con respecto a los millones de euros que han malversado organizando consultas contrarias a Derecho) o en disfrute abusivo de la libertad académica ( ¿es coherente con dicha libertad semejante transferencia fraudulenta de conocimiento de la Universidad a la Sociedad?). Como bien recordó Pedro De Vega, «en la historia de las ideas políticas se juzgan no solamente las ideas, sino también las ideas en cuanto acciones que se plasman y manifiestan en la actividad política completa» ${ }^{125}$.

Me centraré en este caso solamente en la esfera universitaria, sin disquisiciones profundas en torno a una responsabilidad social y política del intelectual que ya fue estudiada por Max Weber. Por supuesto, «todo intelectual en general, y toda teoría política en particular, están, ineludiblemente comprometidos» ${ }^{126}$, lo cual no es susceptible de eludir asimismo el alcance, los límites y la significación de ese compromiso; en otro caso, la tan denostaba impunidad de la casta política puede ir de la mano de impunidad, no menor, de la casta universitaria.

En este sentido, la presencia (más o menos dilatada en el tiempo) de universitarios en la vida política (como asesores o como cargo público electo o de libre designación) es legítima, y hasta cierto punto, una práctica de retroalimentación positiva entre Universidad y Política. Por el contrario, cuando esos universitarios se ponen irresponsablemente en la sombra al servicio de una causa palmariamente contraria a Derecho (como el relatado «procés»), semejante compromiso no es ni legítimo ni tiene visos de legalidad.

124 AEPDIRI: Declaración sobre la falta de fundamentación en el Derecho Internacional del referéndum de independencia que se pretende celebrar en Cataluña (http://www.aepdiri.org/index.php/actividades-aepdiri/ propuestas-de-los-miembros/729-declaracion-sobre-la-falta-de-fundamentacion-en-el-derecho-internacional-del-referendum-de-independencia-que-se-pretende-celebrar-en-cataluna).

125 De Vega García, P.: «Gaetano Mosca y el problema de la responsabilidad social del intelectual», Boletín Informativo de Ciencia Política, n. ${ }^{\circ}$, 1971 (accedo a través de la publicación en la Biblioteca jurídica virtual de la UNAM: https://archivos.juridicas.unam.mx/www/bjv/libros/3/1323/5.pdf, p. 64; último acceso el 2 de septiembre de 2017).

126 Ibidem. 
A este respecto, no mencionaré explícitamente nombres de universitarios, si bien algunos de ellos sean fácilmente identificables por la notoriedad que han adquirido al lado de los dirigentes del «procés», ya desde la crítica acerba a la STC 31/2010 ${ }^{127}$. No obstante, y sin siquiera divagar sobre los beneficios materiales o morales que hayan podido obtener, ¿de qué responsabilidad han hecho gala catedráticos de universidad —entre otros, constitucionalistas, internacionalistas o politólogos- elaborando los diversos informes del Consejo Asesor de Transición Nacional que han respaldado las dos controvertidas leyes catalanas antes citadas ${ }^{128}$ ?; ¿qué grado de neutralidad y de honestidad académica han proyectado al informar oficialmente sobre el pretendido referéndum de autodeterminación de 1 de octubre de 2017 hablando en los mismos términos que los gobernantes catalanes sobre la desproporcionada represión policial española con una tergiversación absoluta del Derecho europeo y pasando por alto las irregularidades del proceso electoral?

Llevada esa misma reflexión a un terreno más académico: ¿No constituiría un sano ejercicio de autoevaluación, por parte de algunos de esos catedráticos, reflexionar sobre el modo de presentar en medios de comunicación la «reinvención» de categorías constitucionales para avalar el «procés»?; ¿cuánta financiación en proyectos de investigación universitaria se ha destinado a propagar el eufemístico derecho a decidir?; ¿es legítimo que esos universitarios impriman un claro sesgo oficialista a alguna revista científica catalana que, aun teniendo carácter público, gozaba hasta hace poco más de un año de un indudable prestigio y mayor pluralismo? ${ }^{129} ;$ ¿es acaso legal —o, contrariamente, una transgresión de los límites de la libertad de cátedra y del derecho a la educación del propio alumnado con una formación respetuosa con la guía docente- que un profesor de Derecho constitucional de una Universidad catalana anuncie a su alumnado que el desarrollo de sus clases va a consistir en «explicar el Derecho vigente en Cataluña» por referencia a las dos polémicas leyes catalanas mencionadas?

127 De nuevo, Álvarez Conde, E., y Tur Ausina, R.: Las consecuencias jurídicas de la Sentencia 31/2010 de 28 de junio del Tribunal Constitucional sobre el Estatuto de Cataluña. La Sentencia de la Perfecta Libertad, op.cit., p. 10: al tomar en consideración las críticas políticas y doctrinales a la citada STC 31/2010, ambos autores entienden preferible prescindir, "por razones obvias, de aquéllas que, aunque utilizando criterios jurídicos, más o menos fundamentados, responden a planteamientos de clientelismo político, lo cual no merece ser tenido en cuenta. Son las efectuadas por los llamados "juristas de corte", que se han limitado a legitimar, con sus opiniones, decisiones políticas que no podían llevarse a cabo, en vez de decir al Gobierno de turno no lo que no desea oír, sino lo que tiene que oír y saber, olvidando la auténtica posición de los juristas en un Estado democrático, y utilizando la vieja y conocida técnica de construir categorías dogmáticas, que únicamente sirven para justificar decisiones políticas previamente adoptadas».

128 En el marco de las medidas de aplicación del art. 155 CE, dispone el Real Decreto 945/2017, de 27 de octubre, en su art. único.Tercero. Supresión del Consejo Asesor para la Transición Nacional, abora llamado Instituto de Estudios de Autogobierno: «Se suprime el Consejo Asesor para la Transición Nacional, creado por el Decreto de la Generalitat de Cataluña 113/2013, de 12 de febrero».

129 Vid. la sección «El proceso soberanista de Cataluña» en el n. ${ }^{\circ} 54$ (junio 2017) de la Revista Catalana de Dret Públic. 
Todo parecido a la realidad con relación a este último interrogante no parece que, lamentablemente, sea ficción.

\section{LA CONSIDERACIÓN DE LAS NORMAS CONSTITUCIONALES POR LOS INSTRUMENTOS INTERNACIONALES: EL MARGEN DE APRECIACIÓN NACIONAL, LA TEORÍA DE LOS CONTRA- LÍMITES Y NOCIONES AFINES}

Tras lo analizado hasta el momento, cabe apuntar que el Derecho constitucional debe asumir, con naturalidad y sin complejos, los cánones establecidos por las normas internacionales. Éstos persiguen y se inspiran en los mismos valores y principios, especialmente en el terreno de los derechos humanos. Por ello mismo, no ha de extrañar que los instrumentos internacionales también se hagan eco de los cánones constitucionales. Resulta entonces pertinente un enfoque bidireccional complementario que examine (en paralelo a la posición de los tratados internacionales en los ordenamientos constitucionales) el lugar de las Constituciones nacionales en los instrumentos internacionales ${ }^{130}$.

Ese lugar se relaciona, en primer término, con la llamada implícita o explícita a las normas constitucionales como requisito procedimental previo a la vigencia de los tratados. Como fórmula implícita (cada Estado Parte tiene sus reglas constitucionales en la materia) se observan frases asépticas como «el presente Pacto está sujeto a ratificación» (art. 48.2 PIDCP de 1966 o art. 26.2 PIDESC). Fórmulas más explícitas, pero menos frecuentes, las encontramos ya en la Convención sobre el derecho internacional de rectificación de 16 de diciembre de 1952, cuyo art. VI.2 estableció que «la presente Convención será ratificada por los Estados signatarios, conforme a sus respectivos procedimientos constitucionales». Más comprensible se perfila esa remisión en el caso de tratados internacionales que implican claramente la transferencia de competencias soberanas por las Partes Contratantes, como sucede en el Derecho originario de la UE ${ }^{131}$.

Dicho lo cual, el reenvío explícito a las normas constitucionales en ocasiones se efectúa utilizando de manera genérica la noción de «Ley» interna. Así sucede en el caso del Convenio de lucha contra la corrupción de Agentes Públicos extranjeros en las transacciones comerciales internacionales de 17 de diciembre de 1997, que establece en su art. 14.1 que «el presente Convenio estará sujeto a la aceptación, aproba-

130 Vid. JIMENA QUESADA, L.: «El lugar de la Constitución en los instrumentos internacionales sobre derechos humanos», em LEO, R.Z.R. (Coord.): Os Rumbos do Direito Internacional dos Direitos Humanos/Ensaios em homenagem ao Professor Antônio Augusto Cançado Trindade (Liber amicorum Cançado Trindade), São Paulo, Sergio Antonio Fabris Editor, vol. 6, 2005, pp. 195-256.

131 Era el caso notorio del Tratado CEE de 1957, cuyo artículo 247 disponía que «el presente Tratado será ratificado por las Altas Partes Contratantes de conformidad con sus respectivas normas constitucionales», redacción reproducida posteriormente en las equivalentes disposiciones del Tratado CE (art. 313) y del Tratado de Funcionamiento de la UE (art. 357). 
ción o ratificación de los signatarios, de conformidad con sus Leyes respectivas». En este último inciso habría que entender «Constituciones respectivas»o, cuando menos, procedimientos constitucionales respectivos. Por lo demás, si la llamada a las normas constitucionales es comprensible para que los instrumentos internacionales sean ratificados y entren en vigor, parece lógico igualmente esa apelación al orden constitucional para proceder a la modificación o enmienda de dichos instrumentos: a título de ejemplo, el art. 18.3 del Protocolo Facultativo de la Convención sobre la eliminación de todas las formas de discriminación contra la mujer de 6 de octubre de 1999 prevé que las posibles enmiendas «entrarán en vigor cuando hayan sido aprobadas por la Asamblea General de las Naciones Unidas y aceptadas por una mayoría de dos tercios de los Estados Partes en el presente Protocolo, de conformidad con sus respectivos procedimientos constitucionales».

Con carácter adicional, algunos instrumentos internacionales se hacen eco de la peculiar forma territorial de los potenciales Estados Partes, señaladamente cuando poseen una marcada descentralización política, con el fin de evitar que el sistema constitucional interno de distribución de competencias constituya una barrera para la ratificación de dichos instrumentos, es decir, para que de cara al exterior no se proyecte un conflicto interno en torno a quién ostenta el treaty making power. Se trata de la conocida como cláusula federal, incluida en instrumentos tan importantes como la Convención de Ginebra del estatuto de los refugiados de 28 de julio de 1951, cuyo art. 41 afirma que «con respecto a los Estados federales o no unitarios, se aplicarán las disposiciones siguientes», destacando a nuestros efectos el apartado b): «en lo concerniente a los artículos de esta Convención cuya aplicación dependa de la acción legislativa de cada uno de los Estados, provincias o cantones constituyentes que, en virtud del régimen constitucional de la Federación, no estén obligados a adoptar medidas legislativas el Gobierno federal a la mayor brevedad posible y con su recomendación favorable, comunicará el texto de dichos artículos a las autoridades competentes de los Estados, provincias o cantones».

Una vez verificadas las condiciones de celebración y entrada en vigor de los Tratados (parte II de la Convención de Viena de 1969, arts. 6 a 25), el art. 26 de dicha Convención establece el principio pacta sunt servanda. En coherencia con ello, resulta lógico que, una vez incorporado al Derecho interno, el propio tratado apele al orden constitucional para favorecer su vigencia. Así, resulta ilustrativo un instrumento adoptado un día antes de la Declaración Universal, concretamente la Convención para la prevención y la sanción del delito de genocidio de 9 de diciembre de 1948, en virtud de cuyo artículo $\mathrm{V}$ «las Partes contratantes se comprometen a adoptar, con arreglo a sus Constituciones respectivas, las medidas legislativas necesarias para asegurar la aplicación de las disposiciones de la presente Convención» ${ }^{132}$. La propia Decla-

132 Ejemplos análogos (se refieren a «procedimentos constitucionales») los ofrecen el art. 2.2 PIDCP o el art. IV de la Convención sobre la imprescriptibilidad de los crímenes de guerra y de los crímenes de lesa humanidad de 26 de noviembre de 1968. 
ración Universal de 1948 apela al respeto de los «derechos fundamentales reconocidos por la Constitución o por la Ley» en el art. 8, lo cual significa que toda Constitución contemporánea debe reconocer derechos y libertades y, por ende, se erige en un complemento y comparte ese ideal común de defensa de los derechos humanos con los instrumentos internacionales. Al hilo de ello, algunos derechos constituyen justamente normas de ius cogens que tienen su traducción en una «tradición constitucional común» que comparten Estados miembros (por ejemplo, en la UE) y que debe protegerse tanto a escala trasnacional como nacional, aun en ausencia de normativa específica $^{133}$.

Si esto es así en clave positiva, es consiguientemente razonable la llamada a las normas constitucionales para el establecimiento de límites, o para apelar al margen de apreciación nacional, sin perjuicio de otras excepciones derivadas de nociones como la identidad constitucional, los contra-límites, o afines.

En cuanto a las restricciones, la cláusula más típica incluida en los instrumentos internacionales alude a «limitaciones establecidas por la Ley» ${ }^{134}$. Ahora bien, la jurisprudencia del TEDH nos muestra que el término «Ley» no debe ser interpretado de manera restringida como equivalente a acto emanado formalmente del Parlamento a través del correspondiente procedimiento legislativo ${ }^{135}$, sino en sentido más amplio como comprensivo de otros actos que ostenten una legitimidad superior o equiparable, ya sea por emanar de la soberanía y derivar del poder constituyente (las normas constitucionales), ya sea por haberse fraguado directamente en el pueblo sin un procedimiento escrito (verbigracia, la costumbre, de especial significación en los sistemas de common law), ya sea por derivar del poder de auto-normación de un colectivo que para él juega con fuerza de ley (pongamos por caso las normas deontológicas aprobadas por grupos corporativos de Derecho público).

Paralelamente, al ponderar el alcance de esas esas restricciones, formalidades o limitaciones, el TEDH ha acudido en su tarea hermenéutica para legitimarlas o no a la noción conexa de «margen de apreciación nacional». Así, ese margen se ha hallado justificado en preceptos constitucionales (STEDH Gitonas y otros c. Grecia de 1 de julio de $1997^{136}$ ), en normas no escritas (de common law en la STEDH Sunday Times c. Reino

133 Tal consecuencia antiformalista se recoge en la Sentencia del Tribunal de Justicia comunitario de 21 de marzo de 1990 (Reino de Bélgica c. Comisión de las Comunidades Europeas, asunto C-142/87), apartado 46. Esa línea ya la había avanzado la Corte de Luxemburgo en el célebre caso Nold de 14 de mayo de 1974 (asunto 4/1973): «al asegurar la salvaguarda de estos derechos, el Tribunal está obligado a inspirarse en las tradiciones constitucionales comunes a los Estados miembros y no puede, por ello, admitir medidas incompatibles con los derechos reconocidos y garantizados por las Constituciones de estos Estados» (apartado 13).

134 Vid. art. 29.2 de la Declaración Universal de 1948.

$135 \mathrm{El} \mathrm{CEDH}$ se refiere en diversas disposiciones «previstas por la Ley» («prévues par la loi» o «prescribed by Law»). Léase CremonA, J.J.: «The interpretation of the word Law in the Jurisprudence of the European Court of Human Rights», Revista del Instituto Interamericano de Derechos Humanos, n. ${ }^{\circ}$ 3, 1986.

136 El fondo del asunto Gitonas y otros c. Grecia versó sobre las causas de inelegibilidad parlamentaria contempladas en el art. 56.3 de la Constitución griega. 
Unido de 26 de abril de 1979, o de derecho consuetudinario stricto sensu — costumbre andorrana- en la STEDH Drozd y Janousek c. Francia y España de 26 de junio de 1992), en códigos deontológicos (STEDH Bartbold c. Alemania de 25 de marzo de 1985), o incluso en otras disposiciones internacionales (STEDH Groppera Radio y otros c. Suiza de 28 de marzo de 1990). En lo que nos concierne, valga una breve reseña a la STEDH Gitonas: el Tribunal de Estrasburgo declaró que no hubo violación del art. 3 del Protocolo n. ${ }^{\circ} 1$, al entender que los Estados gozan de un amplio margen para establecer, «en su orden constitucional», reglas relativas al estatuto de los parlamentarios. En sentido contrario se había pronunciado la desaparecida Comisión europea de derechos humanos el 7 de marzo de 1996, tachando de incoherente y arbitrario el sistema constitucional griego en este punto. Sobre este particular, resulta ilustrativo el voto particular disidente formulado por el miembro español de la Comisión (Sr. Martínez), discrepando del criterio mayoritario con una fuerte crítica al informe que dictaminaba violación del texto convencional europeo: «La Comisión no tiene derecho a erigirse en juez de las leyes, y menos aún de las Constituciones de los Estados miembros. (...) La Comisión — con su argumentación- ha querido introducir una reforma a la Constitución griega y se ha erigido en jurisdicción de apelación respecto al Tribunal Supremo especial griego».

Como corolario de lo expuesto, el art. 27 de la Convención de Viena dispone en clave negativa que «una Parte no podrá invocar las disposiciones de su Derecho interno como justificación del incumplimiento de un Tratado», salvo que se produzca el supuesto contemplado en el art. 46 de la propia Convención, relativo al vicio de nulidad del Tratado por violación manifiesta de las disposiciones internas concernientes a la competencia para contraer compromisos internacionales y que esa violación «afecte a una norma de importancia fundamental de su Derecho interno». Parece obvio que, dada la contundente consecuencia aparejada a dicho vicio (la nulidad del Tratado), la citada causa debe ser objeto de una exégesis restrictiva, lo cual implica interpretar ese último inciso haciendo equivaler «norma de importancia fundamental» a norma de rango constitucional.

Al margen del vicio de nulidad, las jurisdicciones constitucionales han encontrado en ocasiones resquicios para apartarse de estándares internacionales. No es el caso del ya mencionado Auto 86/2011, de 9 de junio (asunto Melloni), mediante el cual el TC español parecía plantear una cuestión prejudicial con respuesta preconcebida a la luz de la jurisprudencia previa del TJUE ${ }^{137}$. A todas luces, en la solución dada mediante la STJUE de 26 de febrero de 2013 (asunto C-399/11, Melloni) parece apostarse con carácter preferente por la armonización en detrimento de la profundización en la protección de derechos fundamentales ${ }^{138}$, confirmando así una posición comunitarista (confirmada con su STC 26/2014, de 13 de febrero) que reconfortaba

${ }^{137}$ El antecedente esencial venía dado por la STJUE de 3 de mayo de 2007 (Advocaten voor de Wereld VZW y Leden van de Ministerraad, asunto C-303/05).

138 El TJUE confirmaba asimismo la interpretación armonizadora a la baja del art. 53 CDFUE propugnada en las Conclusiones del Abogado General Yves Bot. 
al TJUE haciendo prevalecer la dinámica de la integración a través de la armonización en la materia controvertida; lo cual, desde el punto de vista interno, significaba realzar la eficacia integradora del art. $93 \mathrm{CE}$ relegando el juego del art. 10.2 CE ${ }^{139}$.

Lo cierto es que la jurisprudencia Melloni ha seguido confirmándose por parte del TJUE $^{140}$, lo cual seguramente no habrá alejado el fantasma de la teoría de los «contra-límites» ${ }^{141}$ (cuestionando la superioridad del Derecho de la UE cuando se pongan en entredicho los principios y derechos que configuran la «identidad constitucional» ${ }^{142}$ o la «reserva constitucional» nacional $\left.{ }^{143}\right)$. De hecho, el propio TC español ya había evocado dicha problemática con motivo de la Declaración 1/2004, de 13 de diciembre, estableciendo «una reserva de competencia jurisdiccional en su favor en el caso de que el Derecho de la Unión resulte “inconciliable" con la Constitución española» ${ }^{144}$.

En este panorama, otras Jurisdicciones Constitucionales se han sumado a ese diálogo con el TJUE ${ }^{145}$ siendo, sin lugar a dudas, la iniciativa más saludada la llevada a cabo por el Bundesverfassungsgericht Alemán, que dio lugar a la importante STJUE

139 Guillén López, E.: «Spain. The impact of the European Convention of Human Rights and the Charter of Fundamental Rights of the European Union on Spanish Constitutional Law: make a virtue of necessity», en Popelier, P., Van De Heyning, C., y Van Nuffel, P. (Coords.): Human Rights Protection in the European Legal Order: the interaction between the European and the National Courts (Coords.), Cambridge, Intersentia, 2011, p. 334.

${ }^{140}$ Entre otras, SSTJUE de 5 de abril de 2016, Pál Aranyosi y Robert Căldăraru (asuntos acumulados C-404/15 y C-659/15 PPU, apartado 76), o Pawel Dworzecki (asunto C-108/16 PPU, apartado 42).

141 Sobre la teoría de los contra-límites, por todos Cartabia, M.: Principi inviolabili e integrazione europea, Milano, Giuffrè, 1995, pp. 95 y ss.

142 Vid. Balaguer Callejón, F.: «The dialectic relation between the national and the European constitutional identity in the framework of European Constitutional Law», UNIO-EU Law Journal, Vol. 3, n. ${ }^{\circ}$ 1, 2017, pp. 10-24; Cruz Villalón, P.: «Entre proporcionalidad e identidad: las claves de la excepcionalidad en el momento actual», Revista de Derecho Constitucional Europeo, n. ${ }^{\circ} 27,2017$ y, del mismo autor, «La identidad constitucional de los Estados miembros: dos relatos europeos», Anuario de la Facultad de Derecho de la Universidad Autónoma de Madrid, n. ${ }^{\circ}$ 17, 2013, pp. 501-514, GUASTAFERRO, B.: «Beyond the Exceptionalism of Constitutional Conflicts: The Ordinary Functions of the Identity Clause», Yearbook of European Law, Vol. 31, n. ${ }^{\circ}$ 1, 2012, pp. 263-318.

143 Sobre la idea de «reserva de constitucionalidad» en el caso de Francia, puede leerse la Decisión del Consejo Constitucional DC n. ${ }^{\circ}$ 2006-540 DC de 25 de julio de 2006.

${ }^{144}$ Llobera Vila, M.: «La intervención estatal disuasoria del ejercicio de las libertades comunitarias: caracterización del Derecho del Trabajo como obstáculo al comercio intracomunitario», Revista Europea de Derechos Fundamentales, n. ${ }^{\circ} 28,2016$, p. 299-300.

145 Entre otros pronunciamientos relevantes, pueden leerse la STJUE de 28 de julio de 2016 (Ordre des barreaux francophones et germanophones y otros, asunto C-543/14, cuestión prejudicial planteada por la Cour constitutionnelle de Bélgica, sobre sujeción a IVA de servicios prestados por abogacía); o la STJUE de 19 de julio de 2016 (Tadej Kotnik y otros, asunto C-526/14, cuestión prejudicial formulada por el Ustavno sodǐčé, Tribunal Constitucional de Eslovenia, sobre ayudas de Estado a los bancos en el contexto de la crisis financiera). Resulta también de interés la STJUE de 16 de junio de 2016 (Franz Lesar, asunto C-159/15; la cuestión prejudicial fue planteada por el por el Verwaltungsgerichtshof, Tribunal Supremo de lo Contencioso-Administrativo de Austria, tras declararse incompetente previamente el Verfassungsgerichtshof, Tribunal Constitucional austríaco, sobre discriminación por motivos de edad en la determinación de los derechos a pensión de los funcionarios públicos). 
de 16 de junio de 2015 (Gawweiler, asunto C-62/14) sobre el impacto en Alemania del programa de compra de deuda pública del Banco Central Europeo. Efectivamente, por más que los Tribunales Constitucionales se hayan mostrado finalmente abiertos en el plano procedimental a la formulación de cuestiones prejudiciales ${ }^{146}$, debe tenerse presente que la controversia no se plantea únicamente en términos de potencial conflicto entre Jurisdicción Comunitaria y Jurisdicción Constitucional, al no poder quedar en absoluto excluido del diálogo el $\mathrm{TEDH}^{147}$. Nos encaminaríamos, en el marco del constitucionalismo multinivel, a un sistema constitucional de geometría variable que, sustancialmente, vislumbra una única Corte europea de derechos para una sola Carta europea de derechos ${ }^{148}$.

Diversamente, en este polémico terreno, la «doctrina Bosphorus» de presunción del Derecho de la UE con relación al $\mathrm{CEDH}^{149}$ parece llamada a verse exceptuada por matizaciones y puntualizaciones en el marco de un diálogo judicial indefectiblemente imbuido por el principio favor libertatis ${ }^{150}$.

\section{REFLEXIONES FINALES: LA RETROALIMENTACIÓN DE LOS ESTÁNDARES INTERNACIONALES Y CONSTITUCIONALES}

Llegados a este punto, la primera enseñanza que, a modo de recapitulación, nos ofrecen los cuarenta años de vigencia de la Carta Magna española de 1978 es, pese al carácter disperso y a veces lacónico de sus disposiciones en la materia, su potencial de apertura para la recepción de los estándares internacionales, en un movimiento inexorable de internacionalización del Derecho constitucional ${ }^{151}$, puesto que el Derecho constitucional no puede permanecer ajeno a los vientos de la mundialización ${ }^{152}$ o de la globalización ${ }^{153}$.

${ }^{146}$ El encuadre de esa apertura en la obra de Vidal Prado, C.: El impacto del nuevo Derecho europeo en los Tribunales constitucionales, Madrid, Colex, 2004.

147 Gordillo Pérez, L., y Tapia Trueba, A.: «Diálogos, monólogos y tertulias. Reflexiones a propósito del caso Melloni», Revista de Derecho Constitucional Europeo, n. ${ }^{\circ} 22,2014$, p. 269.

148 Spadaro, A.: «Una (sola) Corte per l'Europa», en Falzea, P., Spadaro, A., y Ventura, L. (Coords.): La Corte Costituzionale e le Corti d'Europa, Torino, Giappichelli, 2003, pp. 560-562.

149 STEDH (Gran Sala) Bosphorus Hava Yollari Turzim ve Ticaret Anonim Sirketi c. Irlanda de 30 de junio de 2005.

${ }^{150}$ López Guerra, L.: «El diálogo entre el Tribunal Europeo de Derechos Humanos y los tribunales nacionales. Coincidencias y divergencias», Teoría y Realidad Constitucional, n. ${ }^{\circ} 32,2013$, pp. 140-141.

${ }^{151}$ Se trata del «desafío de la apertura del Derecho constitucional al Derecho internacional», que debe estar presente en la enseñanza del primero, como ha destacado FLAuss, J.F.: «Conclusiones générales. Deux siècles d'enseignement de droit constitutionnel: esquisse d'un bilan», en FLAUss, J.F. (Ed.): L'ensegneiment du droit constitutionnel, Bruxelles, Bruylant, 2000, p. 212-213.

${ }^{152}$ De Vega García, P.: «Mundialización y Derecho Constitucional: la crisis del principio democrático en el constitucionalismo actual», Revista de Estudios Políticos, n. ${ }^{\circ}$ 100, 1998.

153 Gomes Canotilno, J.J.: «¿Revisar o romper la Constitución dirigente?», Revista Española de Derecho Constitucional, n. ${ }^{\circ} 43,1995$, p. 23. 
En consecuencia, la experiencia normativa nacional debe verse como complementaria de la internacional y viceversa, pues la fuente interna y la supranacional se retroalimentan en aras de la «integralidad maximizadora» del sistema global de derechos humanos ${ }^{154}$, lo mismo que se retroalimentan la jurisdicción nacional y la jurisdicción internacional en una deseable acción de sinergia optimizadora ${ }^{155}$. De igual manera, las clásicas fronteras entre monismo y dualismo al abordar el lugar de los tratados internacionales en el orden constitucional se han perfilado tenues hasta difuminarse ${ }^{156}$.

En tal escenario, ha quedado ilustrada en los distintos apartados del presente trabajo la internacionalización de la Carta Magna de 1978 en sus cuarenta años de vigencia y en sus distintas partes, en un decurso aperturista que tampoco es susceptible de ser eludido por el Derecho constitucional en sus distintos bloques. A este respecto, la jurisdicción constitucional no puede permanecer enclaustrada, ni la doctrina constitucionalista ensimismada, so pena de incurrir en una inadmisible banalización del Derecho internacional y del Derecho constitucional que no contribuirá a procurar el fin último convergente de la justicia y del respeto de la dignidad humana ${ }^{157}$.

Por consiguiente, el citado movimiento de internacionalización del Derecho constitucional y de la Carta Magna de 1978, discurre en paralelo a la constitucionalización del Derecho internacional ${ }^{158}$ (con variedad de matices en las «concepciones constitucionalistas del Derecho y del gobierno mundial» ${ }^{159}$ ) y a análoga consideración de los cánones constitucionales por los instrumentos internacionales, en la reseñada sana dinámica de retroalimentación. Un doble movimiento que, desde luego, es más ostensible en clave de europeización del Derecho constitucional o, correlativamente, constitucionalización del Derecho europeo ${ }^{160}$. En este caso, la doctrina constitucionalista sí ha

154 Enfoque y expresión que utiliza Bidart CAMPos, G.J.: «La interpretación del sistema de derechos humanos», Revista del Instituto Interamericano de Derechos Humanos, vol. 19, 1994, pp. 29-31.

155 CANÇADO Trindade, A.A.: «Reflexiones sobre la interacción entre el Derecho internacional y el Derecho interno en la protección de los derechos humanos», Colección «Cuadernos de derechos humanos» de Guatemala, 1995, p. 20.

156 SCHEININ, M.: «International human rights in National Law», en KANSKI, R., y SuKsI, M. (Eds.) An Introduction to the International Protection of Human Rights, Turku/Abo, Institute for Human Rights/

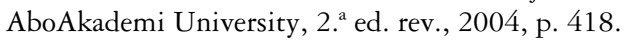

157 Con esta filosofía, SIClARI, M.: Le «norme interposte» nel giudizio di costituzionalità, Padova, CEDAM, 1992, p. 135: «La creación de un ordenamiento internacional orientado a la paz constituye, por lo tanto, un valor cada vez más universal y explícito, y bien puede decirse que en nuestro orden constitucional es la piedra angular de todas las disposiciones constitucionales en esta materia».

158 Escobar Roca, G.: Introducción a la teoría jurídica de los derechos humanos, Madrid, Trama editorial, 2005, p. 145-

159 Vid. Gordillo PÉrez, L.I.: Constitución y ordenamientos supranacionales, Madrid, CEPC, 2012, particularmente pp. 464-471.

160 Entre otras muchas contribuciones, Constantinesco, V.: «¿Hacia la emergencia de un Derecho constitucional europeo?», Cuadernos Constitucionales de la Cátedra Fadrique Furió Ceriol, n. ${ }^{\circ} 8$, 1994; D’atena, A.: «The European Constitution’s Prospects», en Hermann, J.B., y Mangiameli, 
exhibido un claro entusiasmo, mientras que nuestra jurisdicción constitucional se ha mostrado «muy renuente a entrar en estas cuestiones, negando rango constitucional al Derecho comunitario» ${ }^{161}$. El intercambio entre Tribunales Constitucionales seguirá forjando las tradiciones constitucionales comunes ${ }^{162}$, en el marco de un diálogo más amplio con los tribunales supranacionales ${ }^{163}$.

En cualquier caso, la tarea pedagógica de clarificación en cuanto al impacto internacionalizador y europeízador en la Carta Magna de 1978 sigue siendo acuciante, no sólo por cuestiones académicas, sino sobre todo por el modo en que se transmite ese impacto a los futuros operadores jurídicos. Pese a ese recorrido de cuatro

S. (Eds.): The European Union after Lisbon. Constitutional Basis, Economic Order and External Action, Berlin/Heidelberg, Springer, 2012; Díez-PiCAzo, L.M.: «La constitucionalización de Europa», Claves de Razón Práctica, n. ${ }^{\circ}$ 64, 1996); HäBerle, P.: «Derecho Constitucional común europeo», Revista de Estudios Políticos, n. ${ }^{\circ}$ 79, 1993 (del mismo autor, «Per una dottrina della costituzione europea», Quaderni Costituzionali, n. ${ }^{\circ}$ 1, 1999); Rubio Llorente, F.: «El constitucionalismo de los Estados integrados de Europa», Revista Española de Derecho Constitucional, n. ${ }^{\circ} 48,1996$; TORRES Del MORAL, A.: «Relaciones entre la Unión Europea y los Estados miembros según el Tratado constitucional europeo», Revista de Derecho Político, n. ${ }^{\circ}$ 65, 2006, o WeILer, J.H.H.: The Constitution of Europe, London, Cambridge University Press, 1999.

161 Torres Del Moral, A.: Estado de Derecho y democracia de partidos, op. cit., p. 135. El mismo autor (Principios de Derechos Constitucional español. Tomo I: Sistemas de fuentes. Sistema de los derechos, Madrid, Servicio de Publicaciones de la Facultad de Derecho de la Universidad Complutense, 6. ${ }^{a}$ ed., 2010), al acometer la «inserción del Derecho de la UE en el Ordenamiento interno», ha criticado que si bien «el Derecho de la Unión no integra el bloque de la constitucionalidad», la «autoexclusión como órgano de garantía del Derecho europeo es difícilmente aceptable»; con carácter adicional, en caso de duda respecto a una posible colisión «entre una norma de producción nacional y otra de Derecho de la Unión Europea», el juez nacional (incluido el juez constitucional) debe «hacer un reenvío prejudicial al Tribunal de Luxemburgo para que éste decida el alcance y contenido preciso de la norma europea», pp. 263-264.

162 En sus «Palabras en la sesión de apertura de la VI Conferencia de Tribunales Constitucionales Europeos», Manuel García Pelayo (quien presidió dicha Conferencia, Madrid, 22-24 de octubre de 1984; véase el discurso en sus Obras Completas, tomo III, Madrid, CEC, 1991, pp. 3229-3231) sostuvo: «Como pertenecientes al círculo común de la cultura europea, (...) parece clara la importancia que tiene el intercambio de ideas y experiencias entre las jurisdicciones constitucionales europeas, pues si bien es obvio que las decisiones de cada una de ellas sólo tienen vigencia en sus respectivos ámbitos, no es menos cierto que de su doctrina pueden extraerse unos preceptos, unos métodos y unas modalidades de interpretación que trascienden a las circunstancias concretas de cada uno, para adquirir, en muchos casos, una validez generalizada. Común es, en buena parte, nuestra problemática; comunes son, en lo esencial, nuestros valores, y comunes son, en líneas generales, nuestras funciones, (...) parece claro que la confrontación de experiencias de cada Tribunal puede y debe enriquecer la doctrina común y contribuir a la formación de un Ius Publicum Europaeum, lo que, sin duda, constituirá una aportación de primer rango para la integración de Europa».

163 Gordillo PÉrez, L.I., y Martinico, G.: Historias del país de las hadas. La jurisprudencia constitucionalizadora del Tribunal de Justicia, Madrid, Civitas/Thomson Reuters (Cuadernos Civitas), 2015, p. 20. Vid. igualmente CARTABia, M.: «Fundamental Rights and the Relationship among the Court of Justice, the National Supreme Courts and the Strasbourg Court», en VV.AA: 50ème anniversaire de l'arrêt/50th anniversary in the judgment in Van Gen den Loos 1963-2013, Luxembourg, Office des publications de l'Union européenne, 2013, pp. 155-168. 
décadas del orden constitucional establecido en 1978, no es extraño en foros de expertos y aplicadores del Derecho, ubicar los instrumentos emblemáticos del Consejo de Europa (el Convenio Europeo de Derechos Humanos o la Carta Social Europea) como fuentes del Derecho de la UE o bajo la tutela del TJUE. Y un déficit añadido: cuando se llega fácilmente a discernir entre ambas organizaciones europeas, se otorga sin más prevalencia al canon de la UE sobre el parámetro del Consejo de Europa en caso de aflorar conflicto interpretativo entre sus instancias máximas respectivas de control (TJUE, por un lado; TEDH y Comité Europeo de Derechos Sociales, por otro).

Semejante déficit tiene entre sus causas, sin duda, la configuración político-constitucional de la UE como entidad supranacional sui generis o como tertium genus entre la Organización internacional clásica y el Estado constitucional, en conexión con el hecho de haber transferido de manera más neta a aquélla el ejercicio de competencias soberanas y la posibilidad de emanar Derecho derivado o secundario que impacta directamente en la ciudadanía. Ahora bien, esta circunstancia, unida a la base habilitante constitucional diversa (en el caso de España) prevista para asumir los instrumentos constitutivos de cada organización internacional (art. 93 CE para la UE, pero no sólo, y art. 94 CE para el Consejo de Europa), no implica que, una vez incorporados los distintos estándares internacionales, unos se pongan por encima de otros en caso de conflicto, que sigue unas reglas (señaladamente, interpretativas) establecidas por la Convención de Viena de 1969 (arts. 31 a 33); bajo cuyo paraguas, por cierto, se encuentra asimismo el Derecho de la $\mathrm{UE}^{164}$.

Paradójicamente, son las normas de la UE, tanto originarias como derivadas, las que reenvían a las del Consejo de Europa a efectos interpretativos ${ }^{165}$, y no a la inversa. Y ello sin perjuicio de la mencionada «doctrina Bosphorus» asumida por el TEDH como presunción de conformidad del Derecho de la UE con el CEDH, pero no por el Comité Europeo de Derechos Sociales para aceptar esa misma presunción con la Carta Social Europea ${ }^{166}$.

164 Vid. art. 5 de la Convención de Viena.

165 En el caso de la Carta Social Europea, su presencia en el Derecho primario y secundario de la UE se ilustra exhaustivamente en el Documento de trabajo del Comité Europeo de Derechos Sociales titulado La relation entre le droit de l'Union européenne et la Charte sociale européenne/The relationship between European Union law and the European Social Charter, Strasbourg, 15 de julio de 2014, en particular pp. 8 a 23 (acceso en: https://www.coe.int/fr/web/turin-european-social-charter/documentation).

166 A título de ejemplo, véase el rechazo de la «doctrina Bosphorus» en dos Decisiones del Comité Europeo de Derechos Sociales de 23 de junio de 2010 de resolución de sendas reclamaciones (n. ${ }^{\circ}$ 55/2009, Confederación general del trabajo, CGT c. Francia, y n. ${ }^{\circ}$ 56/2009, Confederación francesa de directivos-Confederación general de ejecutivos, CFE-CGC c. Francia). Vid. Asimismo Stangos, P.: «Les rapports entre la Charte sociale européenne et le droit de l'Union européenne. Le rôle singulier du Comité Européen des Droits Sociaux eet de sa jurisprudence», Cabiers de droit européen, n. ${ }^{\circ} 2,2013$, especialmente pp. 367-375. 
Al margen de lo precedente, es sabido que los parámetros internacionales (más concretamente, los supranacionales de la UE) han condicionado las dos reformas de la Carta Magna de 1978 habidas hasta la fecha (la del art. 13.2 CE en 1992 y la del art. 135 CE en 2011). En el momento presente, independientemente de la acentuación del debate sobre la reforma constitucional a cuenta de la situación en Cataluña, no parece prioritario suscitar otra vez la mención de la UE en una disposición específica (un art. 93.bis CE, precedido por una mención en el Preámbulo a la voluntad de la nación española de participar activamente en el proceso de integración europea ${ }^{167}$, como tampoco considero pertinente abrir un controvertido nuevo proceso constituyente derivado en materia de derechos sociales, siendo en este supuesto más factible sustancialmente y sencillo procedimentalmente asumir las dos asignaturas pendientes de dimensión europea en el terreno social, esto es, la aceptación en nuestro orden constitucional del procedimiento de reclamaciones colectivas ante el Comité Europeo de Derechos Sociales establecido mediante el Protocolo de 1995 y de la Carta Social Europea revisada de 1996.

Ambos compromisos sociales ya fueron asumidos por nuestros países vecinos (Francia, Italia o Portugal) y vienen reclamados con fuerza en el contexto del conocido como «Proceso de Turín» (lanzado en octubre de 2014 por el Secretario General del Consejo de Europa) para reforzar la efectividad de la Carta Social Europea (como «Pacto Europeo de Democracia Social» o «Constitución Social de Europa») y las sinergias con la UE, y habría de venir asimismo coherentemente dinamizado por el nuevo «Pilar Europeo de Derechos Sociales» (propuesto por el Presidente de la Comisión Europea en su Discurso sobre el estado de la Unión ante el Parlamento Europeo el 9 de septiembre de 2015) ${ }^{168}$. En definitiva, la asunción de esos compromisos configura un signo de consolidación del constitucionalismo social que, acompañado por la efectividad cotidiana de los demás instrumentos internacionales ya incorporados al ordenamiento jurídico español, manifestarán la inequívoca madurez constitucional de nuestra Carta Magna de 1978.

${ }^{167}$ En la VIII Legislatura (2004-2008), bajo el mandato del Presidente del Gobierno José Luis Rodríguez Zapatero, se barajaron cuatro reformas de la Constitución de 1978 (la ya «clásica» reforma del Senado, la introducción en el texto constitucional de la denominación oficial de las Comunidades Autónomas, la mención expresa a la Unión Europea y la supresión de la desigualdad de trato de la mujer con respecto al hombre en la sucesión a la Corona). Reviste interés el Informe sobre modificaciones de la Constitución Española aprobado por el pleno del Consejo de Estado el 16 de febrero de 2006 (N. ${ }^{\circ}$ E/2005), 382 pp. (especialmente, apartado III: «Recepción en la Constitución del proceso de construcción europea», pp. 40 y ss.).

${ }^{168} \mathrm{La}$ propuesta se concretó en la Comunicación de la Comisión al Parlamento Europeo, al Consejo, al Comité Económico y Social Europeo y al Comité de las Regiones sobre el establecimiento de un pilar de derechos sociales, Bruselas, 26 de abril de 2017, $\operatorname{COM(2017)250~final.~}$ 
Title:

Internationalization of the 1978 Spanish Magna Carta: A Sign of Constitutional Maturity

\section{Table of Contents:}

1. Preliminary issues: the influence of international standards in the drafting of the 1978 Constitution and the need for consistency with the reality of an integrated State at supranational and international levels. 2. Subsequent issues: the weight of constitutional jurisdiction confinement in light of international parameters. 3. Further questions: the presence of a self-absorbed constitutionalism with respect to international sources in general and relatively enthusiastic about European sources in particular. 4. Constitutional clauses on the open acceptance of international standards: particular focus on human rights instruments. 5. The constitutional approach international treaties and the so-called control of conventionality. 6. The favourable impact of international standards on the set of constitutional values, principles and rights. 7. The impact of international standards on the organization of powers. 8 . The positive role of international instruments in defending the constitutional order: 8.1. Internationalization of the constituent function and the weighting of constitutional amendments. 8.2. International standards and constitutional jurisdiction. 8.3. The inadmissible trivialization of both International and Constitutional Law. 9. International instruments's regard for constitutional norms: the margin of (national) appreciation, the counter-limits and related notions doctrine. 10. Final remarks: the feedback between international and constitutional standards

\section{Resumen:}

La presente contribución adopta como hipótesis de partida la relativa influencia de los estándares internacionales en la redacción de la Constitución de 1978 y la absoluta necesidad de adaptación a la realidad del Estado supranacional e internacionalmente integrado. En este sentido, un primer enfoque permite comprobar que, a pesar del juego potencial de las disposiciones constitucionales de apertura internacional, y tras cuatro décadas de vigencia de la Carta Magna Española de 1978, la justicia constitucional y la doctrina constitucionalista no han mostrado una actitud clara y abierta hacia las exigencias jurídicas internacionales, con la excepción de un relativo entusiasmo hacia los parámetros europeos.

En efecto, en la parte central del artículo, el análisis de los cuarenta años constitucionalismo democrático bajo la Constitución de 1978 revela, primeramente, un déficit de interpretación basado en soluciones internacionales más favorables, así como una incorrecta e inexplorada concepción del impacto de los tratados internacionales en el sistema constitucional de fuentes. En segundo término, se examina la proyección positiva de los estándares internacionales tanto en la «parte dogmática» (valores, 
principios y derechos constitucionales) como en la «parte orgánica» de la Constitución (separación de poderes y organización territorial del poder), sin olvidar el peso de los instrumentos internacionales en la defensa del orden constitucional (mecanismos ordinario - tribunal constitucionaly extraordinario — reforma constitucional-). En tercer lugar, se somete a escrutinio la responsabilidad social de la Universidad en sus tareas de enseñanza y de investigación (especialmente en situaciones domésticas conflictivas), con objeto de transferir un conocimiento avanzado a la sociedad sin banalizar o trivializar la importancia del Derecho internacional y del Derecho constitucional en la defensa democrática del orden constitucional. Por último, se completa el análisis propuesto a través de la toma en consideración del lugar que también ocupan las normas constitucionales en los tratados internacionales y el impacto de nociones como margen de apreciación nacional, identidad constitucional y otras.

La conclusión principal del trabajo consiste en sostener la necesaria retroalimentación de los estándares internacionales y constitucionales, puesto que esas sinergias positivas (incluido un diálogo judicial global) seguirán propiciando el fortalecimiento del sentimiento constitucional bajo una Carta Magna Española de 1978 inserta en un contexto cada vez más globalizado.

\begin{abstract}
:
This papers adopts as a starting hypothesis the relative degree of influence of international standards in the drafting of the 1978 Spanish Constitution and the absolute need to accommodate to the reality of an integrated State at supranational and international levels. In this sense, a first approach shows that, despite the potential role of constitutional clauses opening to international standards, and after four decades since the entry into force of the Spanish Magna Carta of 1978, constitutional justice and constitutional doctrine have not shown clear nor open behaviour towards international legal requirements, with the exception of its relative enthusiasm towards European parameters.

Indeed, in the main part of this paper, the analysis of the past forty years of democratic constitutionalism under the 1978 Constitution reveals, first and foremost, an interpretative deficit based on more favourable international solutions, as well as an incorrect and unexplored view of the impact of international treaties within the constitutional system of sources of law. Secondly, the positive impact of international standards is examined in connection with both the «dogmatic part» (constitutional values, principles and rights) and the «organic part» of the Constitution (separation of powers and territorial organization of the State), without forgetting the weight of international instruments in defending the constitutional order (ordinary — constitutional court — and extraordinary — constitutional amendment- mechanisms). Thirdly, the social responsibility of Universities in their teaching and research (especially in conflicting domestic situations) is submitted to scrutiny, in order to show its key role in trans-
\end{abstract}


ferring advanced knowledge to society without trivializing the importance of both international law and constitutional law in the democratic defense of the constitutional order. Finally, the place that constitutional norms occupy in international treaties, as well as the impact of notions such as (national) margin of appreciation, constitutional identity and others, are proposed so as to complete the analysis.

The main conclusion of this paper holds the necessary feedback of international and constitutional standards, since these positive synergies (including a global judicial dialogue) will continue to promote the strengthening of a «constitutional feeling» under the 1978 Spanish Magna Carta, which is inserted in an increasingly globalized context.

\section{Palabras clave:}

Internacionalización del Derecho Constitucional - Constitucionalización del Derecho Internacional - Espíritu de Apertura - Constitucionalismo Multinivel - Diálogo Judicial Global - Control de Convencionalidad Principio favor libertatis

\section{Key words:}

Internationalization of Constitutional Law - Constitutionalization of International Law - Spirit of Openness - Multilevel Constitutionalism Global Judicial Dialogue - Control of Conventionality - favor libertatis Principle 